\title{
Power Two-Wheelers as an Element of Sustainable Urban Mobility in Europe
}

\author{
Sławomir Dorocki * (D) and Dorota Wantuch-Matla
}

Citation: Dorocki, S.;

Wantuch-Matla, D. Power

Two-Wheelers as an Element of

Sustainable Urban Mobility in

Europe. Land 2021, 10, 618. https://

doi.org/10.3390/land10060618

Academic Editor: Thomas Maloutas

Received: 5 May 2021

Accepted: 5 June 2021

Published: 9 June 2021

Publisher's Note: MDPI stays neutral with regard to jurisdictional claims in published maps and institutional affiliations.

Copyright: (c) 2021 by the authors. Licensee MDPI, Basel, Switzerland. This article is an open access article distributed under the terms and conditions of the Creative Commons Attribution (CC BY) license (https:// creativecommons.org/licenses/by/ $4.0 /)$.
Department of Entrepreneurship and Spatial Management, Institute of Geography, Pedagogical University of Krakow, Podchorążych 2, 30-084 Kraków, Poland; dorota.wantuch-matla@up.krakow.pl

* Correspondence: slawomir.dorocki@up.krakow.pl; Tel.: +48-698-838-616

\begin{abstract}
Nowadays in Europe, there is a noticeable increase in the popularity of power two-wheelers (PTW). This is largely due to the increase in urban transport problems. The aim of the study was to present the changes in urban mobility in terms of the use of power two-wheelers. In relation to this process, the activities of local authorities and organisations related to PTW traffic were also presented to adapt the city infrastructure to the traffic of two-track vehicles in selected European countries. The study used numerical data analysis methods and data from an online survey of motorcyclists in Poland as well as an online search of planning materials from the authorities of selected European cities. Based on the results obtained, communication by PTW vehicles can be considered one of the possibilities for developing alternative transport in cities. Their advantage is both high mobility and economic value. PTW vehicles are also a part of an exhaust reduction policy. The best solutions to promote this mode of transport are the reduction of parking fees and the availability of public service lanes. Supporting PTW communication is included in communication policies and brings especially positive spatial results in cities such as Barcelona, London or Vienna.
\end{abstract}

Keywords: mobility; power two-wheelers; Europe; urban; PTW

\section{Introduction}

The process of globalisation and, in the case of the European space, integration, which has been progressing since the middle of the 20th century, have increased the mobility of the population [1]. The modern communication infrastructure not only enables but also conditions local economic and social development. Just as during the industrial revolution at the beginning of the 20th century the rail network was the direction of economic development and progress, today, individual transport accessibility largely determines the possibility of local socio-economic development. The process of increasing mobility can be observed both globally and locally. The communication problem is particularly important in the case of large agglomerations and urbanised areas. Growing communication problems connected with a high concentration of people and an increasing need for mobility, mainly connected with commuting to work, have been growing for years. This is why since the beginning of the 21st century, there has been a growing interest in the development of alternative means of transport to cars in many European countries. It is also related to the fact that transport functions as the only sector in which reducing energy consumption and pollutant emissions proves to be extremely difficult [2].

The urgent problem associated with the worsening climate crisis has led to the increasing popularity of the idea of climate change mitigation through the pursuit of more sustainable mobility and smart-mobility services [3-5], which in European countries are promoted, among others, in the form of the concept of creating so-called Sustainable Urban Mobility Plans (SUMPs) and related guidelines for member states [6]. One of the objectives of these documents is "the sustainable development of all relevant modes of transport, while encouraging a shift to more sustainable modes" [7]. 
The development of alternative transport takes place in two strands of action. One is the development and popularisation of public transport [8] and the development of mobile services. Mobility as a Service (Maas) is the activity of developing combined mobility. This mobility is mainly public transport in combination with other transport modes, such as taxis, cars, bike and moped rentals [9] and social transport (e.g., Uber) [10]. The development of public transport often entails high costs (e.g., construction of tram networks or underground lines) and is characterised by spatial inertia [11]. In many cases of historic cities, due to their unique urban characteristics, the creation of new public transport networks is impossible to implement (e.g., dense historic buildings next to narrow communication routes). In addition, the use of public transport can have an adverse effect on psychosocial feelings (lack of self-control, lack of self-esteem and independence, and low social prestige) [10]. The COVID-19 pandemic has also had a negative impact on the perception of public transport and its future development [11-15].

In addition to Mobility as a Service (MaaS), another developing process today is the use of big data in transport and mobility. Big data is a paradigm that is currently attracting worldwide interest, especially in the transport industry. It is a combination of disruptive technologies and new concepts, such as smart city. In this context, big data is considered the efficient management of all the data required by the transport sector to provide safer, cleaner and more efficient means of transport, and for users to personalise their transport experience and mobility [16].

Another way to reduce car traffic in cities is to create an infrastructure dedicated to alternative forms of transport and, more precisely, to individual mobility, both private and public. Two-wheeled vehicles are among the preferred modes of transport. These are both non-motorised vehicles (e.g., bicycles) and motorised vehicles (power two- or threewheelers, PTW), which also include three-wheelers. In urban conditions, electric vehicles are gaining popularity, as they are part of the policy to reduce exhaust emissions [17]. However, the spatial development of cities and the processes of suburbanisation have increased commuting distances [18]. Therefore, communication with electric bikes can only be limited to short distances, which is related both to the allowed speed of assisted bicycles (max. speed $25 \mathrm{~km} / \mathrm{h}$ and motor power $250 \mathrm{~W}$ ), while all electric-powered vehicles above $250 \mathrm{~W}$ are treated as mopeds (L1e-A) and require additional permissions and charges. Electric vehicles with speeds above $45 \mathrm{~km} / \mathrm{h}$ are treated as mopeds (L1e-B moped) or motorbikes (L-class) in Europe. Despite a noticeable increase in the distance travelled by e-bikes compared to traditional bicycles, this increase is small and does not exceed $20 \mathrm{~km}$ [19]. In the case of electric scooters (EV), despite the fact that they can cover about $70 \mathrm{~km}$ on a single charge, an additional, necessary element of the infrastructure is places for charging vehicles [20]. This process is still time-consuming and takes $4-8 \mathrm{~h}$, depending on the model [21]. Therefore, irrespective of the type of propulsion (electric, hybrid or diesel), PTWs are currently the main alternative to cars in suburban transport $[2,22,23]$. This is determined by both the technical parameters of these vehicles (speed and range) and their high availability.

An important element in the creation of PTWs is the policy of national and local authorities to reduce car traffic and adapt the existing road infrastructure, nowadays adapted mainly for car and pedestrian traffic, and the needs of cyclists [24-26]. The top-down policy is mainly limited to the measures to reduce emissions by introducing standards for exhaust emissions and technical parameters of vehicles (in the case of Europe, this is the so-called Euro standard) $[27,28]$. The introduction of new solutions for small engines (e.g., replacement of carburetor by injection) and reduction of their power resulted in a decrease of emissions by about $20 \%$ in comparison to cars. All measures taken, both top-down and local, are aimed at improving the quality of life of city dwellers. Nowadays, an increase in the number of motorcycles is observed mainly in cities. This is due to increasing urbanisation and related transport problems [25,26,29-33]. Additionally, the increase in population density related to urbanisation increases the costs of car use [34-41] 
and the efficiency of public transport [42-44], which in turn influences decisions to abandon car ownership in cities.

The 21st century has seen an increase in the number of motorised two-wheelers in most European countries. Although two-wheeled mobility has a long transport tradition mainly in southern Europe [45], nowadays, there is a noticeable increase in the number of single-track vehicles also in the developing countries of Central and Eastern Europe [46,47] and in the north of the continent. The increase in the number of two- and three-wheeled motor vehicles in Europe is mainly related to socio-economic conditions [48]. On the one hand, it is the result of the increase in the wealth of the society in which these vehicles are a luxury product $[34,49-51]$ and determine the level of social development and car saturation [52]. On the other hand, the impact of the global financial crisis confirmed the great importance of the financial factor. The deteriorating financial situation influenced the choice of cheaper means of transport, including the abandonment of cars in favour of two-wheelers, e.g., in Spain and Greece [46].

When analysing the change in the number of PTWs in Europe, it should be noted that in the case of motorbikes, i.e., vehicles with an engine capacity of over $50 \mathrm{cc}$ (vehicle category L2e), no major differences are noted in their definition in individual countries. Problems occur in the case of mopeds (engine capacity below $50 \mathrm{cc}$ and speed limit up to $45 \mathrm{~km} / \mathrm{h}$-vehicle category L1e). Depending on the European country, mopeds have different conditions of use. In many countries, they are not subject to registration and insurance, which makes it impossible to verify their number. For example, in Belgium, mandatory moped registration has existed since 31 March 2014; in Greece, mopeds are not registered with the Ministry of Transport but with local police stations under the Ministry of Civil Protection; in Italy, the obligation for mopeds in circulation before July 2006 to have a permanent number plate was introduced on 13 February 2012, but they are not registered with the Public Car Register; in Hungary, mopeds have been subject to registration since 2014 but you cannot carry a passenger. In addition, despite the fact that most countries belong to the European Union, there are different requirements for mopeds and light motorbikes (up to $125 \mathrm{cc}$ engine capacity). Although most European countries have adopted the AM category (authorising driving a moped), the age limits for this category vary (e.g., from 13 years in Iceland). In Poland, as well as in some other countries, people over 18 can drive a moped without additional qualifications. Driving light motorbikes (engine capacity up to $125 \mathrm{cc}$ ) can be done in many European countries on the basis of a driving licence (category B) after fulfilling additional requirements (e.g., several years of driving experience or an additional course). In some countries, there are also vehicles with speed limit of $25 \mathrm{~km} / \mathrm{h}$ (e.g., Iceland, Denmark, the Netherlands), which can be driven on cycle paths. This flexible approach to the use of mopeds and light motorbikes contributes to the popularity of these vehicles in everyday communication and their widespread use in many European countries [53].

Due to these differences in the approach to L1e vehicles, for the analysis of the change in the number of single vehicles in Europe at the beginning of the 21st century, attention should be paid to the above issues and consideration should be given to the countries for which complete fleet data were obtained.

In analysing the development of PTWs, it is important to note the fundamental differences in their use on the European continent. Climatic conditions are an important factor differentiating the popularity of two-wheelers, which is evident in the north-south arrangement. While in the south, mopeds and motorbikes are used as one of the main means of transport, in the north, they are treated more as a luxury good and used for recreational purposes [54]. Another factor influencing the different use of PTW vehicles are urban and rural areas. Traditionally, two-wheelers have been the domain of rural areas, but nowadays, two-wheelers are becoming an important element of everyday communication in cities. Additionally, in urbanised areas, the ages of PTW users and the share of women are increasing, compared to rural areas. There is a wide variation in the culture of motorbike use across Europe, which is also related to differences in the development of the automotive 
industry and historical economic conditions. Another important factor is the age structure of the population. Because of the age restrictions on driving cars, two-wheelers were often the only means of transport (apart from public transport) available to young people. Nowadays, due to the introduction of medical examinations for drivers over 70 in some European countries, some drivers are forced to give up their cars and choose alternative means of transport, such as mopeds [55].

Other important elements are the legal conditions relating to the possibility of using PTW and the costs of car maintenance. This is particularly important in cities where the authorities deliberately restrict car ownership. An example is the authorities of Krakow (Poland) who, in 2017, eliminated 3000 out of 21,000 parking spaces and are pursuing a policy of extending paid parking zones. This is to reduce car traffic in favour of pedestrian traffic. At the same time, a large part of the roadway has been excluded from car traffic in favour of public transport or cycling.

Mobility can be seen as a basic human activity, as it arises from the need to reach for different activities, such as work, leisure, personal management and household [56]. In the current conditions of rapid global changes, the role of transport and mobility has become particularly important $[57,58]$. The fast and significantly burdening natural environment development of transport that took place at the turn of the 20th and 21st century influenced the development of the concept of sustainable development also in relation to the forms and ways of the mobility of people and goods.

The constant increase in the number of motor vehicles and their use mainly results in pollutant emissions from the combustion of motor fuels in motor vehicles, which contribute to the destruction of the ecosystem and endangers human health. The inconveniences associated with daily traffic, mainly in urban areas, are important problems associated with the use of motorised transport [59]. Due to the fact that about $73 \%$ of the population in EU countries lives in cities, more and more importance is attached to the quality of life in these areas. A very important parameter for this assessment is transport [60]. City dwellers expect a high level of life quality, so a sustainable urban transport policy, aiming to change the structure of urban travel, must gain the acceptance of the inhabitants and thus can be implemented effectively $[58,61]$. The idea of sustainable development combines economic development, environmental protection and social justice in an effort to increase the quality of life, both for present and future generations. The general objective of the transport policy of sustainable urban transport development should be the creation of conditions for the efficient, safe and economically effective movement of people and cargo within the framework determined by the activities available for this, natural resources and possibilities of discharging pollutants into the environment [62]. As formulated in Managing Mobility for a Better Future EPOMM's Visions and Goals for 2020 (European Platform on Mobility Management), transport mobility has both an environmental and an economic development and welfare dimension. Most of the solutions used within the framework of sustainable development revolve around the issue of reducing car traffic in cities [63]. The limitation of car traffic is realised, among others, by the development of public transport and alternative forms of individual transport.

One solution is to support and develop PTW. The main advantages of PTW are great gas mileage, taking up less parking space, fast transport in city traffic and small carbon footprints [64-72]. It should, therefore, be recognised that PTWs (including electrically powered vehicles) are part of sustainable urban transport. The aim of this study is to present the changes taking place in the mobility of urban residents in terms of the use of two-wheeled motor vehicles. In relation to this process, the actions of local authorities and PTW-related organisations aimed at the adaptation of the city infrastructure to the traffic of single-wheel vehicles in selected European countries are presented. Due to the fact that this topic has so far been dealt with mainly in terms of bicycle traffic, the focus will be on facilities aimed at PTW users. The presented actions of the local municipal government are complemented with the results of a survey of motorbike and moped users in Poland. The aim of this article is not to find new solutions for urban PTW but to present existing 
solutions applied in selected European cities. It will identify good practices in relation to suggestions from PTW users.

The aim of the research was also to find out whether urban policies related to transport infrastructure take PTW into account in the process of moving towards sustainable mobility-how this is done and what benefits it brings for PTW users. Additionally, this was verified with the expectations of PTW users on the basis of an online survey conducted in Poland.

The structure of this article is as follows. Section 2 describes the methodology used in the analysis of the change in the number of PTW vehicles in Europe. Section 3, as a kind of background for research activities, presents the examples of adaptation of street space in cities to the needs of PTW users, as well as activities carried out for their implementation, in cities where PTWs have been or are gaining more and more popularity. Their situation in the space of Polish cities is also briefly outlined. Section 4 describes the results of the research. Section 5 discusses the development and future of PTW in the context of the challenges of finding alternatives to car transport in cities. Section 6 concludes the paper.

\section{Materials and Methods}

The paper uses basic methods of numerical data analysis. Statistics showing the changes in the number of PTWs were obtained from the European Association of Motorcycle Manufacturers (ACEM) and national statistics. The analysis of statistical data showing the change in the number of vehicles was used in earlier studies of the topic [73,74]. Due to the lack of available European-wide data, the analysis includes data for Austria, Belgium, Bulgaria, Croatia, Cyprus, Czech Republic, Denmark, Estonia, Finland, France, Germany, Greece, Hungary, Iceland, Ireland, Italy, Latvia, Liechtenstein, Lithuania, Luxembourg, Malta, the Netherlands, Norway, Poland, Portugal, Romania, Slovakia, Slovenia, Spain, Sweden, Switzerland, and the United Kingdom.

In addition, the article uses data obtained from an internet survey carried out with the help of the Ścigacz.pl web portal: Motocykle, motory, skutery, ścigacze (www.scigacz.pl, accessed on 5 May 2021). An online survey was conducted among 545 motorcyclists (88\% were men aged 25 to 45) in Poland in 2018-2019. In Poland, only about 6 women per 100 men have a category A driving licence entitling them to drive motorbikes; however, this proportion is still increasing. The structure of the surveyed people reflects, to a large extent, the demographic structure of PTW users in Poland. The survey consisted of both open and closed questions. It concerned the characteristics of two-wheel vehicle use in Poland: the characteristics of two-wheel motor vehicle users, the type of vehicles used and their purpose. The survey aimed to identify the main problems in moving PTW vehicles in urban spaces and the ways to improve them. Internet surveys, despite their drawbacks, are widely used in social and sociological research $[75,76]$. In order to demonstrate the activities undertaken by local authorities for the development of infrastructure and solutions dedicated to PTW vehicles, a query was conducted on available online planning documents of selected European cities and national recommendations or sectoral guideline publications regarding PTW communication. The cities analysed included those with the greatest availability of documents and with the highest saturation of two-wheelers but a different transport culture (Barcelona and Vienna). Barcelona, with the highest number of motorbikes and mopeds per population in Europe (and the second largest city in Europe after Rome in terms of motorbikes), is an important example of sustainable transport development efforts [46,77]. Additionally, Barcelona is one of the safest European cities in terms of traffic accidents [78]. In the case of Vienna, despite its lower number of vehicles per population, it is one of the cities in Europe with the highest efforts to reduce traffic in the central business district (CBD). Other cities include Stockholm and London. Stockholm, although located in the north of Europe where the motorbike season is relatively short, is also introducing policies to support alternative forms of transport in the city. A cordon charge in Stockholm has led to $24 \%$ fewer commuter trips by car (motorcycles and scooters are exempt), with most people switching to public transport, and Gothenburg following 
the same example. The U.K. started, in 2005, the Government's Motorcycling Strategy. Motorcycles are allowed into bus lanes on most of the capital's red routes. Other benefits include reduced motorcycle journey times and fewer carbon dioxide emissions. It also contributes to Vision Zero, working towards the elimination of road traffic deaths and serious injuries [79]. London is, therefore, an example of the implementation of a policy to support PTWs in Europe. Among the Central European countries, Poland was selected as an example of a country with one of the largest increases in mopeds and motorbikes per person in Europe in the 21st century. In the case of Poland, Krakow was chosen as an example to analyse the actions of local authorities to popularise PTWs. The city is the second largest Polish city after Warsaw. However, according to the TomTom Traffic Index report, Krakow is one of the most congested Polish cities (after Łódź) and ranks 9th in terms of time spent in traffic jams in Europe [80]. In addition, the time spent in traffic jams is increasing in this city at the fastest rate in the country. Krakow is also the first Polish city to have taken steps to popularise single-track transport. It was the first city in Poland to open a bus lane for motorbikes and mopeds. These vehicles are also exempt from payment in paid parking zones.

\section{Tendencies in the Evolution of the PTW Mobility in European Countries}

Communication by motorbikes and mopeds is very popular in Europe. During the period analysed (1994-2019), the number of PTWs has continuously increased from about 2.5 million to 0.4 million (Figure 1). A noticeable increase in the number of single-track vehicles occurred at the beginning of the 21st century as a consequence of the economic development of Central and Eastern European countries [81]. At the same time, as the number of vehicles increased, there was a change in their structure. The share of mopeds dropped from $54 \%$ to $32.5 \%$ during the study period. These changes also have much to do with the economic transformations taking place in the newly acceded countries of the European Union. Poland may be an example of such a country. Another important factor in the increase in the popularity of motorbikes in the old EU countries are legislative changes allowing people holding a category B driving licence (passenger cars) to drive light motorbikes. Such changes took place, among others, in Spain in 2004 [53], as can be seen in the graph (Figure 1). The transport policy and the traffic problem, mainly in big cities, influence the increase in PTW interest in European cities. Of the country cases analysed, only in the case of the United Kingdom was the increase in the number of PTWs interrupted during the financial crisis and is now remaining stable.

There are, therefore, three main types of PTWs used in Europe's urban space. On the one hand, there are the southern countries (e.g., Italy, Spain, Greece), where the highest number of vehicles per population was recorded (more than 100 PTWs per 1000 people). The second type is the economically developed countries of Western Europe with a high level of urbanisation, e.g., Benelux, Switzerland or Austria. These countries are characterised by a high share of vehicles and a developed transport infrastructure. Another group is made up of Central and Eastern European countries, where the development of PTW only started at the beginning of the 21st century, along with the economic development and financial possibilities of the inhabitants. Examples are Poland, the Czech Republic, Slovakia, Croatia, Hungary or Estonia (Figure 1). Depending on climatic and historical conditions, the attractiveness of PTW communication within these groups varies.

According to the average number of vehicles per 1000 people in Europe, there was an increase from around 39.3 in 1994 to 67.8 in 2019. This was due to an increase in the number of vehicles in Central and Eastern European countries caused by access to the cheap, second-hand market from the EU and new vehicles from Asia. In southern European countries, on the other hand, the crisis influenced the choice of a cheaper mode of transport. An additional factor was the professional activation of women and their increased mobility. Thus, the highest increases (more than 50 vehicles per 1000 people) were recorded in countries such as Greece and Slovenia. High positions are held by the countries in the north of the continent, such as Poland and Estonia (about 40 vehicles per 1000 people) as 
well as Finland, Belgium, the Netherlands, Liechtenstein and Iceland, which is linked to the level of urbanisation.

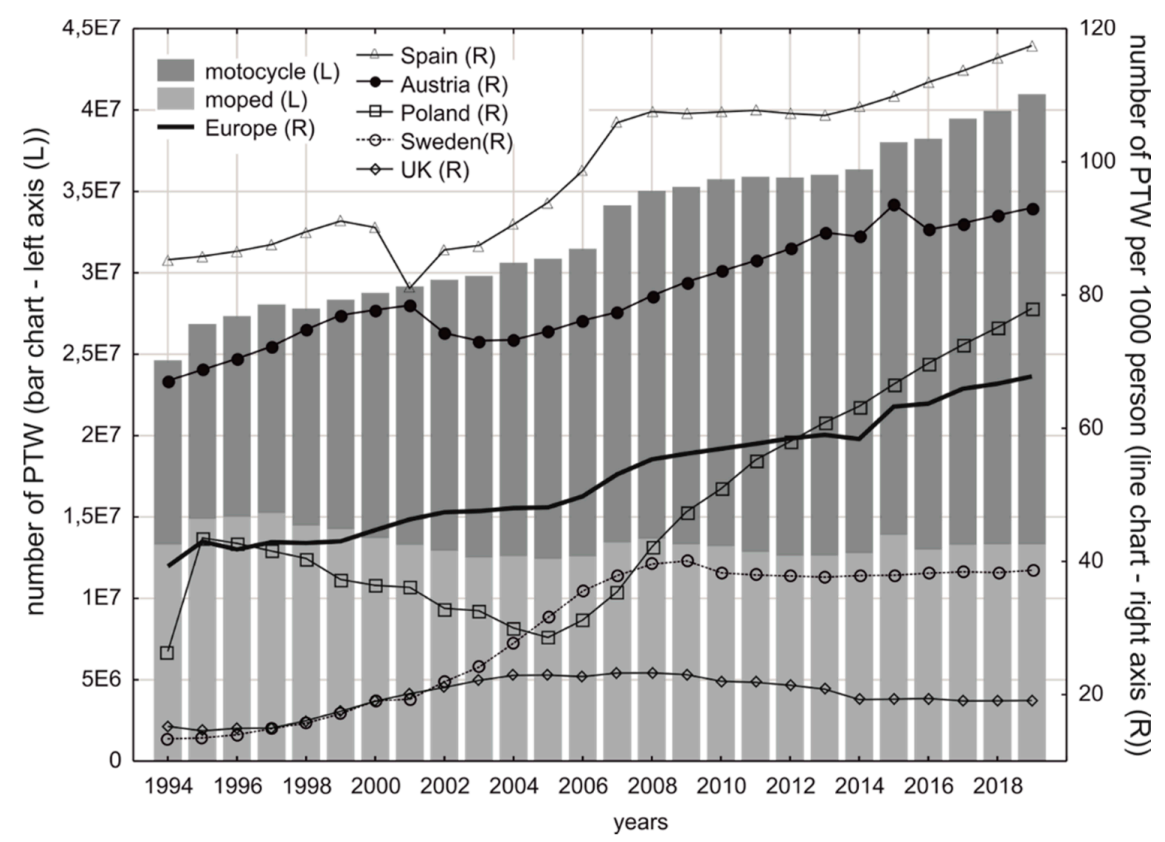

Figure 1. The number of PTW vehicles in Europe and numer of PTW calculated per numer of inhabitants in selected European countries in the years 1994-2019. Author: S. Dorocki.

On the one hand, it resulted from an increase in the wealth of the society and the demand to meet consumption needs (Eastern Europe). An example is Poland, where the financial social policy introduced in 2015 resulted in an increase in vehicle purchases. On the other hand, the development of the popularity of two-wheelers was related to the process of urbanisation and increasing traffic problems in the cities.

\section{The PTWs' Presence in Public Space Design and City Planning Strategies}

The extreme popularity of motorbikes and scooters in some countries, such as Italy and Spain, among others, has led to the introduction of ad hoc solutions dedicated to them in urban areas. They usually refer to the location of parking spaces dedicated exclusively for PTWs. Much less frequently, they refer to broader and systemic measures to strengthen the safety of their use by adapting urban spaces for their needs. Although much is being done to improve the safety of car and pedestrian traffic, measures for single-track traffic still lag behind the main trend [82]. For this reason, among others, it invariably remains perceived as having a high risk of collision and injury [82-84]. The growing interest in this type of mobility, also in the context of the increasing popularity of e-PTW and electric vehicles, is prompting many cities to look for solutions, not only in the field of traffic engineering, but also in spatial and planning terms, which will improve not only the safety, but also the comfort of such vehicles. The period of pandemics and restrictions on travel by urban transport modes has further intensified and confirmed the need for better management of PTW traffic in urban spaces [13]. Regulations and guidelines for the organisation and design of streets for PTW traffic may appear at the national level as a kind of indication to be applied at the regional, local level as well as within the policies of municipal city authorities. Valuable studies presenting universal design standards for PTW also function as a kind of guideline at an international level and are usually the result of work and research carried out on behalf of associations, federations of motorcyclists as well as motorbike manufacturers (e.g., IMMA International Motorcycle Manufacturers' Association).

Planning records are often dominated by regulations defining solutions primarily for cars with quantitative indicators of parking spaces per household. These vary from city to 
city and can also vary between developments within the same city. Sometimes, however, as in the case of the U.K., higher level documents, such as Planning Policy Guidelines, suggest that parking facilities for motorbikes and scooters should be considered. This is not mandatory, but many local authorities have taken up the idea and see it as an opportunity for positive and environmental changes in the structure of local mobility. In many countries, however, it is often at the initiative of local municipalities to test and implement innovative mobility solutions.

Particularly interesting activities for the accommodation of PTW in traffic and urban public spaces are currently being undertaken in Spanish cities, especially in Barcelona, where the willingness to undertake large-scale, systematic actions is strongly apparent.

\subsection{Barcelona, the Laboratory of the 21 Century PTW Mobility}

In the first decade of the 21st century, Barcelona experienced a significant increase in the number of PTW users, which ranked it among the first European cities in terms of the highest number of motorbikes per capita [46]. In Barcelona, the process of continuous adaptation, revalorisation and revitalisation of public spaces has been going on continuously for more than one hundred and fifty years. By striving to create optimal living and working conditions, Barcelona has made urban design its calling card [85]. Recent decades have also seen an intensification of efforts in Barcelona for large-scale and multifaceted transformations of urban public spaces to implement the idea of sustainable mobility. For Barcelona, the last decades of the 20th century and the beginning of the 21st century were the time of a gradual and consistent strengthening of the role of the so-called urban design culture and an era of strategic urban projects that made it a kind of urban laboratory, whose successes were already identified at the end of the last century as the so-called Barcelona model [86]. The redevelopment of existing spaces and the shaping of new public spaces, especially those related to the layout of urban streets and squares, became, some decades ago, some of the key tools for the transformation of the city, following the principle expressed by Oriol Bohigas, chief urban planner since 1980 [87], that "the city is a public space" [82] (pp. 144-145). At the same time, in the last decade, there has been a significant reduction in the amount of public transport space that was previously dedicated to individual car traffic, with $10 \%$ reduction, additional restrictions on parking, but also on keeping cars in the city, and additional lanes for public transport vehicles and bicycles. Today's layout of Barcelona's streets has evolved from the development pattern outlined by Ildefonso Cerda and, despite the passage of time, has proved flexible enough to allow numerous facilities for motorbikes and mopeds to appear in its streets and squares. It is not insignificant that most of today's street grid is one-way, except for a few of the largest streets of particular importance that run through the entire city, forming, together with diagonal arterials, a clear, hierarchical street system [85]. The first parking spaces for motorbikes appeared in Barcelona in 1983 [88]. Over time, more have been added, along with a growing infrastructure dedicated to single-track vehicles, not only motorised, but also bicycles, electric scooters and, more recently, scooters. Since 2005, the public transport company Barcelona de Serveis Municipalis has been implementing a comprehensive mobility concept, including a local management plan for on-street parking zones-AREA de Barcelona-as well as forty public car parks located throughout the city-(B:SM Parking). In the AREA de Barcelona plan, in addition to indicating the types of parking zones, there are also areas intended exclusively for parking motorcycles and scooters, covering over 50 thousand public parking spaces-available $24 \mathrm{~h}$ a day and free of charge [89]. In the following years, a number of solutions related, among others, to the organisation of motorised single-track traffic were introduced by the Comprehensive Sustainable Mobility Policy Plan, the so-called El Pla de Mobilitat Urbana 2012-2018 (PMU), now replaced by a further version for the period 2019-2024. Both take into account the issue of motorised traffic in terms of strengthening road traffic safety, reducing the problems of transport exclusion, and promoting walking, cycling and public transport [90]. Within PMU, there also appeared an idea of so-called Superblocks, selected fragments of the city consisting of 
9 quarters and streets connecting them, where a significant reduction of wheeled traffic and motorbike traffic was introduced in favour of pedestrian and bicycle traffic. The car and motorbike traffic infrastructure, also due to the assumption of lowering noise pollution within the superblocks, was moved outside their area and run only on their circumference. In 2009-2010, special design solutions for motorbike traffic, the so-called Zonas avanzadas para motocicletas-ZAM [91]—were introduced in Barcelona, not yet as widely known at the time as they are today. They are placed at junctions at traffic lights, in front of cars and also just in front of pedestrian crossings. They were intended to increase the safety of two-wheelers users and are still in use today, although studies show that their effectiveness is low, and in some cases, they may even increase the risk both within the zone itself and in the space about 30 metres ahead [91,92].

Since 2018, a program of improving and expanding the network of motorcycle parking lots has been implemented here.

As part of it, locations with particularly high motorbike traffic have been identified and the re-arrangement of existing motorbike parking zones has begun, so that in 2018, among other things, the number of available spaces was increased by 883 street stalls, locating clusters of them in the areas of low visibility for traffic users, e.g., in front of pedestrian crossings at intersections (these are often grouped with the bike parking areas of the city's biking system).

At the same time, the number of spaces in the public underground car parks has also been increased by redesigning the existing ones and making better use of the space around the internal structural columns. Attractive parking tariffs have also been proposed within the city's public underground car parks, in agreement with their private managers [93]. The AREA de Barcelona plan has introduced a special organisation of visual information concerning the different types of vehicles in the different parking zones-parking spaces for motorbikes are marked in the road surface with white and vertical road signs [89].

General design standards for the design of different integrated types of traffic in cities with historic and highly touristic character, including parking solutions for motorbikes, are contained in documents held by the Spanish national institution Dirección General de Tráfico. In some cities, local guidelines can be found for the design of public street spaces, including all traffic and parking arrangements. Basic guidelines for the location of motorbike parking facilities and their parking in the street space are also available in Barcelona (Figure 2). One of the studies of this kind is also the Madrid municipal document, as follows.

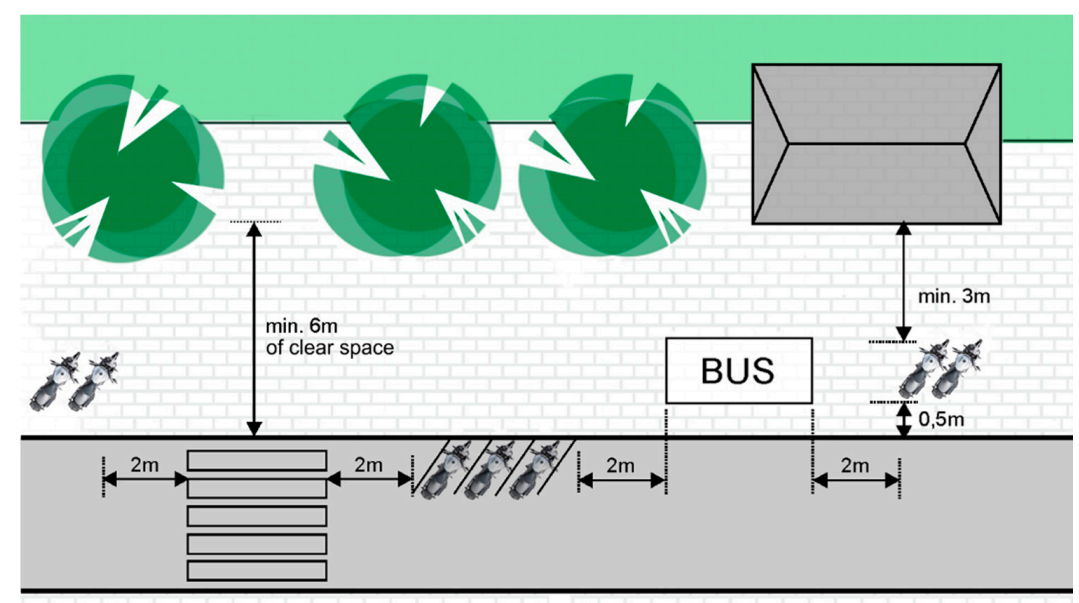

Figure 2. Basic parameters regarding the location of parking zones and parking of motorbikes and scooters in Barcelona (elaborated, based on Barcelona City Hall brochure: https: / www.barcelona.cat/ mobilitat/sites/default/files/Proposta\%20fullet\%c3\%b2\%20FINAL.pdf; accessed on 9 February 2021). 
The city of Madrid's municipal document "Instrucción Vía Pública del Ayuntamiento de Madrid" is such a document that includes suggestions for spatial solutions or even basic parameters for the size of parking spaces for different types of vehicles, including motorbikes [94] (Figure 3).
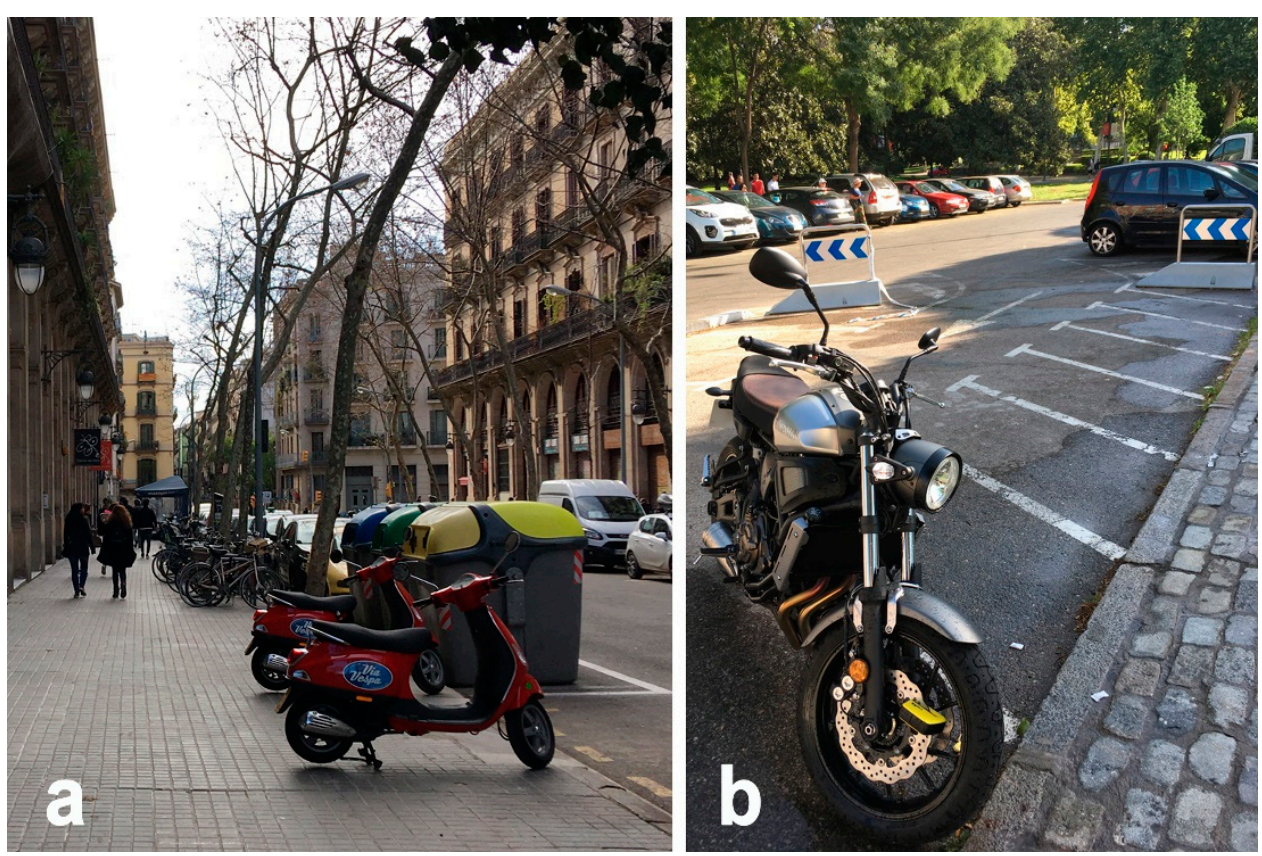

Figure 3. Motorbikes and scooters on the streets of Barcelona (a) and Madrid. (b) Source: Authors' archives (photo W. Kilar (a), I. Jastrzębska-Dorocka (b)).

Single-track mobility management solutions are also part of activities in other Spanish cities. In Seville, where there is also a network of parking spaces for motorbikes, pilot projects have been prepared for the implementation of an electric scooter system, but also for the extension of the car park network for shared mobility. In order to implement this measure, an inventory of the existing network of car parks, including motorbike ones, was undertaken and the reconstruction or expansion of the latter was considered crucial in the process of promotion and implementation of the electric scooter movement, which would share parking space with PTW vehicles [95].

\subsection{Road Design Guidance for PTW's in Great Britain}

In the U.K., the popularity of motorbikes had declined significantly since the 1950s (in favour of motorised traffic) before re-entering a period of growth in the 1990s and then remaining at a similar level since 2000. In 2012, there were over 1.2 million motorbikes and motor scooters, indicating a 70\% increase in numbers over 1994 figures (IHE). The current figure is 1.25 million [96]. Scooters, increasingly electric, are also becoming more popular-largely among young people in the context of commuting to school, for short distances [97].

A high awareness of the need to take into account the specifics and needs of motorcycle traffic in urban space and, more generally, in the organisation of the communication space of non-urban roads and motorways, is, however, evident in many publicly available documents-both planning documents and project guidelines [97-101]. Nationally, the British Parking Association (BPA) and the Institute of Highway Engineers (IHE) motorbike bays design guidelines combine certain statutory parameters with research-based guidelines to identify optimal design solutions. One of the most important and broadest studies to which numerous planning documents at the regional or local level refer are the Guidelines for Motorcycling, which in this strict context, include issues related to the following, among others: street design, their equipment, signage, parking lots and 
traffic engineering, and also topics related to the maintenance of road infrastructure and education. The document provides a number of very detailed indications, such as turning radii, street surface gradients, street cross-section design, organisation of roundabouts, visibility of motorcyclists, quality and uniformity of pavement materials, location and parameters of warning signs, guardrails, furnishing of space along the road and street strip, kerb parameters, parking areas and even protection of PTW vehicles against theft from public places-all this in urban and non-urban conditions, etc. The document also refers to the issue of traffic organisation, including, for example, the thread of the possibility of allowing motorbikes in bus lanes [102]. This solution has been tested in the U.K. in several cities since 1995, and the research and tests carried out on the subject were so satisfactory that in 2012 in London, the full possibility of using bus lanes was granted, although it may involve time limitations. Although a commonly used solution in the U.K. are the so-called Advanced Stop Lines-i.e., the so-called cycle locks at intersections, dedicated exclusively to cyclists-it has not yet been decided to allow their use also by motorbikes [103]. There are no specific standards for motorbike parking in the U.K. transport planning documents (Planning Policy Guidelines) although PPG13: Transport encourages consideration of including standards for motorbike parking in the preparation of local planning documents, but some local level documents do present them. The reference here are the studies by organisations such as The Motorcycle Industry Association or the British Motorcyclists' Federation (BMF). For the precise parking guidelines developed by the FMO, the brochure "Parking for Motocycles and Scooters. A Resource Guide" even refers to the previously discussed Guidelines for Motorcycling by IHE [104].

In the scope of designing parking bays proposed by BPA, they should be marked with appropriate horizontal signs. The suggested sizes of a single parking space are larger compared to the Spanish parameters, especially in the case of extra-urban traffic. This is due to the size of large tourist motorcycles [105]. Regardless of urban or non-urban locations, larger bays and dedicated motorbike parking lanes most often do not actually have dedicated individual parking spaces. The IHE guidelines for the location and design of motorbike parking indicate the main principle that "effective motorbike parking is $>>$ near, clear, secure and safe to use $<<"$ [102] (Figure 4).

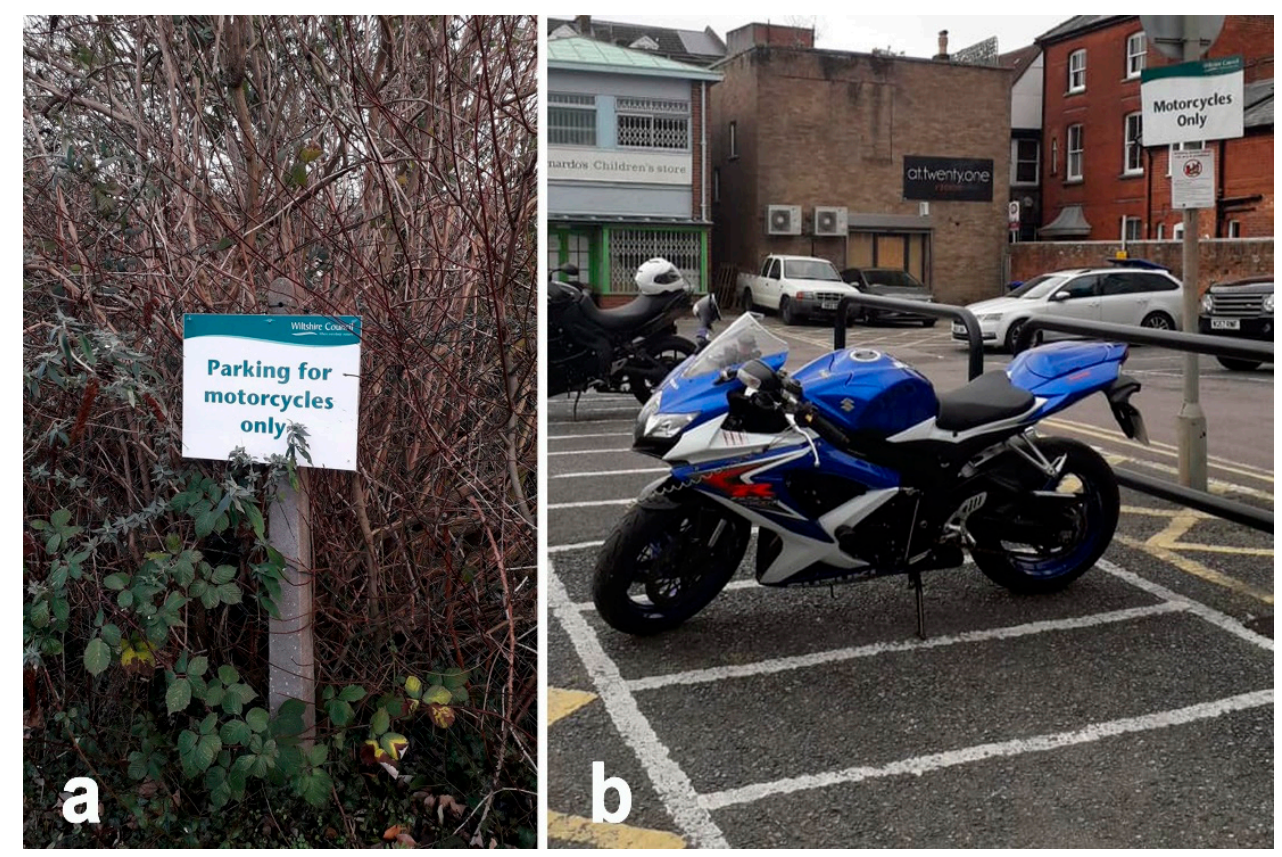

Figure 4. Great Britain: (a) vertical and horizontal street signage for motorcycles can be often found in the cities but also on the countryside, e.g., nearby shops; (b) special motorcycles' zone in use. Source: Authors' archives (photo E. Burdzińska). 


\subsection{Sweden and Stockholm}

Motorbike traffic is quite popular in Sweden-it has tripled since the 1990s [106] (p. 3). In 1997, the national strategy document "Together for Vision Zero" was produced in Sweden, calling for intensified efforts to reduce road traffic casualties by 2020. Over the past 20 years, the strategy has brought a significant decrease in fatalities, but the topic of motorcycle traffic safety has not been recognised by the satisfactory environment associated with it. In 2014, only one out of 290 Swedish municipalities local planning documents dealt with motorcycles and scooters [106] (p. 13). In 2016, the Swedish government announced the update and continuation of the Vision Zero concept with the perspective of the socalled "Renewed Commitment to Vision Zero. Intensified efforts for transport safety in Sweden". However, the most vigorous activity for improving the safety of motorcycle and scooter users and introducing provisions regulating issues related to motorcycle traffic into legislative documents has been carried out since 1963 by the Sveriger Motor Cyklister association. On the occasion of the 2008 OECD International Forum on Motorcycle Safety in Lillehammer, the association published "The Motorcycle Vision 1.0", and in 2014, an updated study called "The Motorcycle Vision 2.0" was produced, which directly addressed various aspects of motorbike accident prevention issues. In addition to issues of safety and driving culture, and analysis of the main causes of accidents, a separate chapter was devoted to a more motorcycle-friendly transport system space.

There is a problem of the typology of protective barriers in the collision by which many motorcyclists die, as well as slippery, uneven or poorly maintained surfaces and gravel on roads, which are also factors that contribute to high accident rates. In 2019, SMC published a guide for shaping roads that are safe for motorcyclists. It was only in 2016 that a study published by The Swedish Transport Administration entitled "Increased Safety on Motorcycles and Mopeds Combined strategy version 3.0 for the years 2016-2020" appeared. "Increased Safety on Motorcycles and Mopeds Combined strategy version 3.0 for the years 2016-2020" recognised the issue of increasing interest in the use of motorised and electric scooters as well as mopeds, the definition of which was first included in the traffic legislation in the same year [107]. In 2018, in turn, the so-called "Stra-tegy for Livable cities" appeared to support the trend of the increasing popularity of motorbikes, scooters and electric mopeds [108].

In addition, the so-called "Stockholm Declaration", drawn up on the occasion of the Third World Road Safety Conference, emerged in February 2020. It also included provisions for developing regulations and measures for improving the safety of motorised and electric single-track vehicles [109]. Among Swedish cities, Stockholm has for years been regarded as a unicycle-friendly city. It was also the first city in the world to allow PTW vehicles to drive in bus lanes. On the city's streets, you will find numerous, specially marked parking areas for motorbikes and scooters (Figure 5).

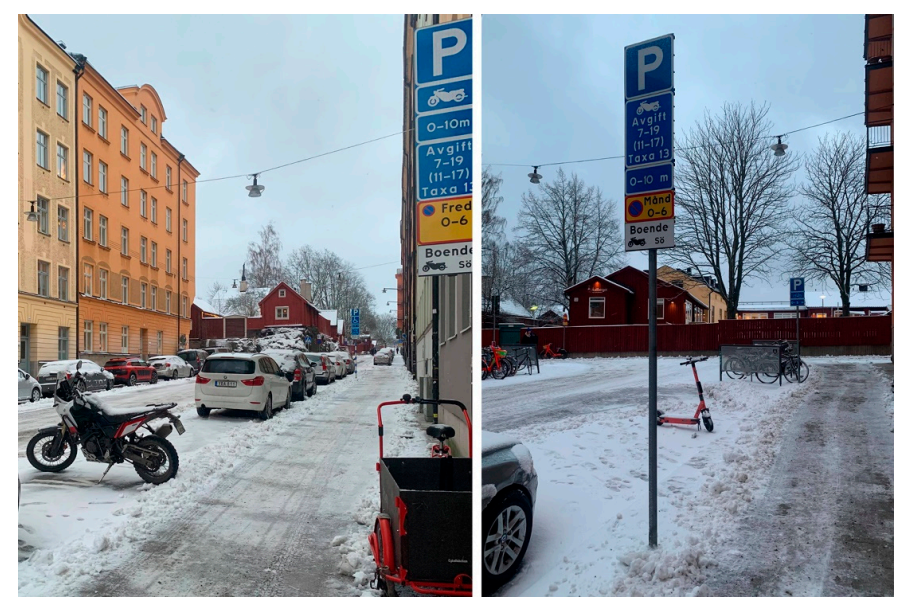

Figure 5. Examples of parking spaces for motorbikes in Stockholm. Source: Authors' archives (photo D. Gunnarsson). 
In 2017 , the city government increased parking fees for motorcyclists but with the onset of the pandemic, the decision was made to allow motorbike designated parking spaces to be used without charge [110].

\subsection{PTW's Presence City Planning Strategies and the Case of Vienna}

More and more cities are including motorbike traffic in their mobility policy and in their thinking about the development of public spaces related to road infrastructure. In the case of Vienna, the city focuses primarily on the development of the public transport infrastructure and a network of cycle paths as well as alternative means of individual transport-electric scooters, scooters, segways, etc. As part of a broader city development strategy called Stadtentwicklungsplan-STEP 2025, the Mobility Plan for Viennaemphasises the aim of reducing private combustion vehicle traffic from the current $28 \%$ to $15 \%$ by 2030 . At the same time, however, the plan also mentions a new mobility culture and multimodalism as goals, as well as the effects of extending Vienna's public transport system with other, innovative methods of travel. The movement of two-wheelers-scooters and motorbikes-is also included in the strategy. The mobility plan provides for the creation of, among other things, parking and rental points for bicycles, scooters, etc. [105]. According to the plan, there were 46.7 motorbikes per 1000 inhabitants in Vienna in 2014 [111] (p. 26). Their popularity has grown over the years and there are now an estimated 70,000 of these types of vehicles moving around the city. Consequently, they are also appreciated here as an alternative to cars, due to their lower fuel consumption, faster commuting and less occupation of public space by dedicated parking spaces [112]. Currently on the map of Vienna, motorbikes can be parked in specially designated parking bays (Figure 6), the locations of which can be found on interactive maps, on official city websites as well as via the city's mobile applications (Figure 7). According to the plan, a network of parking spaces for scooters and bicycles is to be expanded in the city-the role of the former has been emphasised in the context of the safety of school commuting of children and young people, as well as the concept of creating parking and rental zones, the so-called mobility points for scooters and motorbikes [73] (p. 65). In recent years, motorbike traffic has also been allowed on selected sections of bus lanes within the city [113].
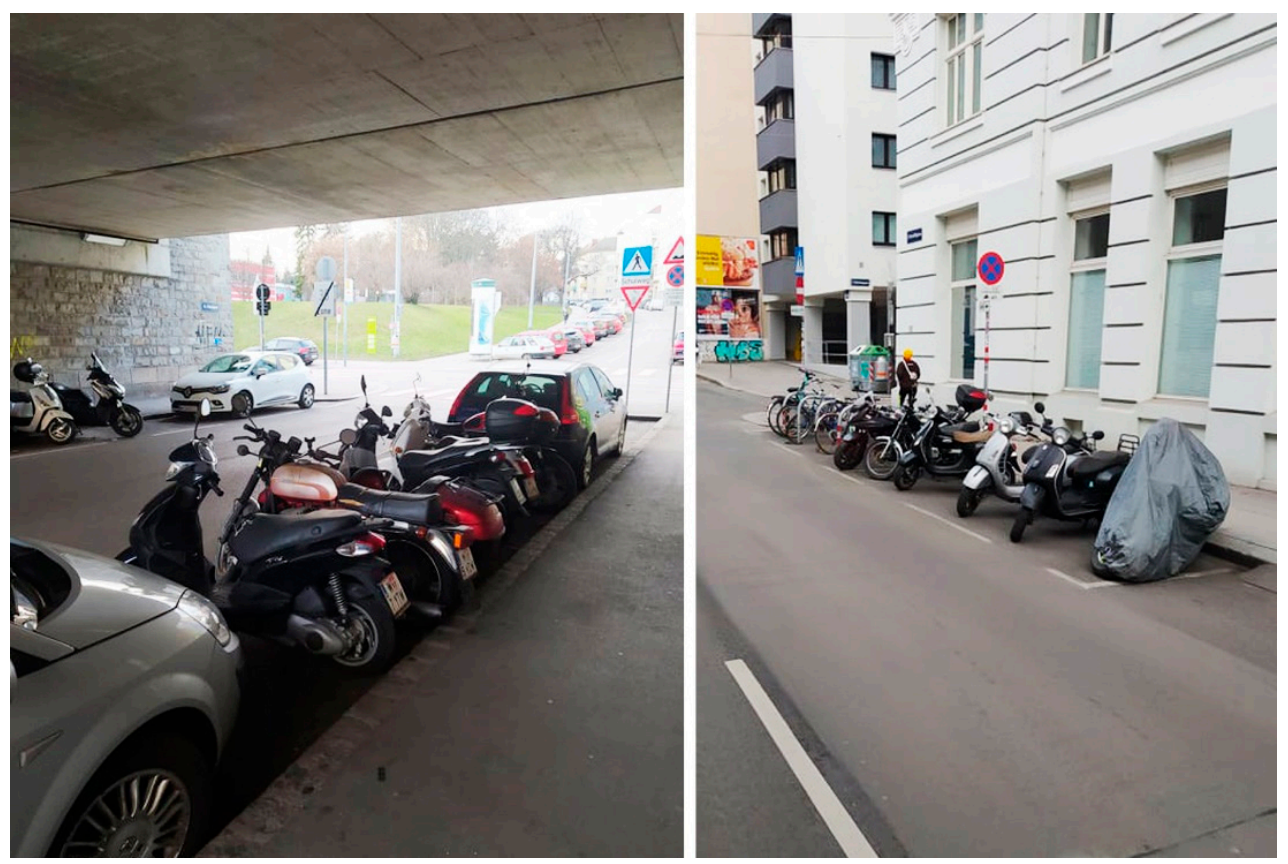

Figure 6. Separate parking zones for PTW bikes in Vienna. Source: Authors' archives (photo Ł. Rygałło). 


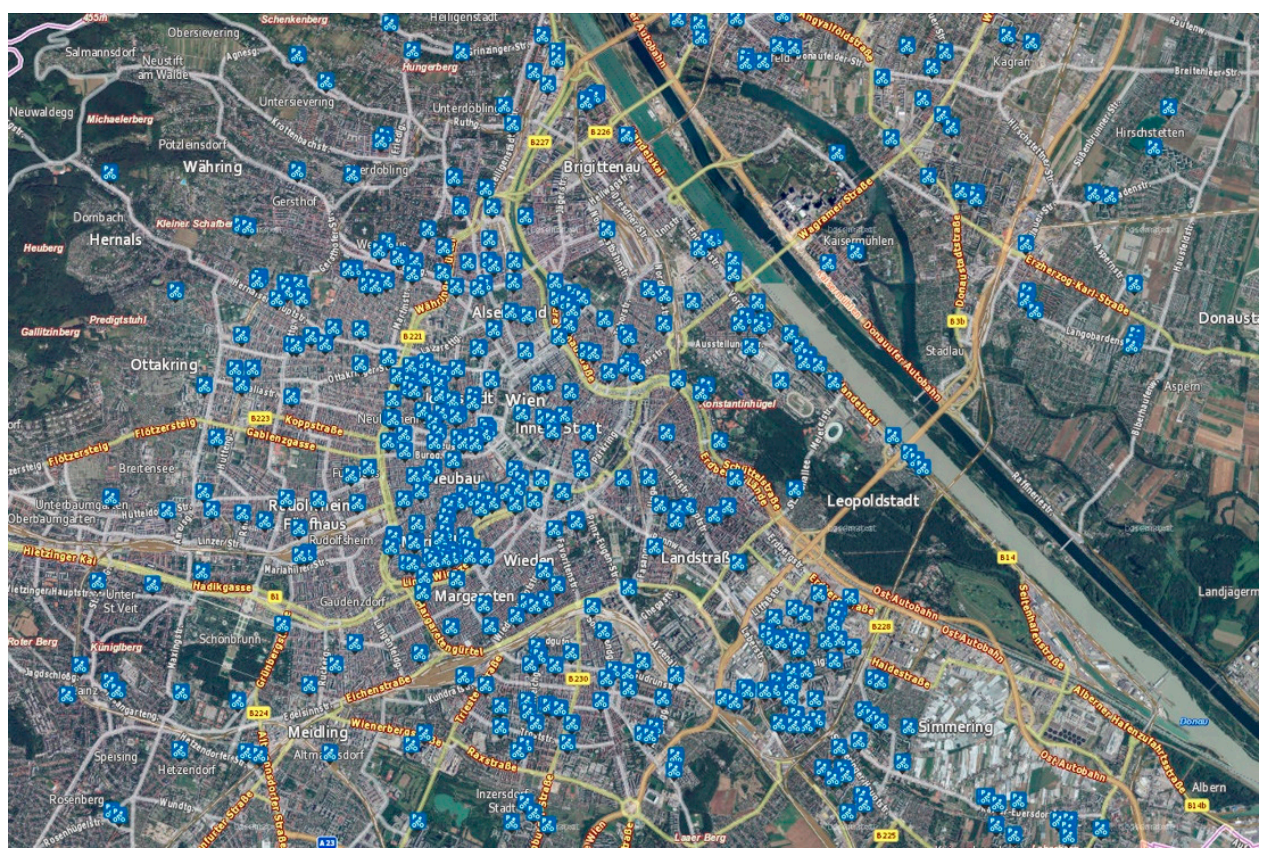

Figure 7. Distribution of parking zones for motorbikes within Vienna. Source: https:/ /m.wien.gv.at/ stadtplan $/$ \#base $=$ luft\&layer $=$ motorradabstellplatz\&zoom $=13 \& l a t=48.2095 \&$ lon=16.417 (accessed on 9 February 2021).

An interesting case is also Brussels, where the city authorities signed the "Mobility adapted to motorized two-wheelers" charter (French: Mobilité adaptée aux deux-roues motorisés), which includes a declaration of taking action to strengthen the safety of motorcycle and scooter users. The city undertakes therein, in the event of the modernisation or construction of new street spaces, e.g., parking lots for PTW vehicles are located there, appropriate pavement materials and road markings will be used, and all obstacles and objects obstructing visibility will be limited [114]. Motorbikes and scooters can park on pavements provided that sufficient space is left for pedestrians. In addition, there are few car parks in the city centre designated exclusively for motorcyclists.

\subsection{PTWs in Poland and the Case of Kraków}

The Polish Act on Road Traffic takes into account the movement of motorbikes, mopeds, bicycles and bicycle trolleys among the various types of vehicles, and yet the definition of a car park, contained in the regulation on technical conditions to which buildings and their location should conform, refers only to cars. It is worth mentioning that the very definition of parking, in the statutory provisions, appeared only in 2018.

Thus, under Polish conditions, both PTW parking and design guidelines for separating parking spaces or creating dedicated solutions for them in street space are not formalised issues. As a consequence, motorcyclists and users of scooters or mopeds park in car parking spaces or leave their vehicles on pavements. Individual initiatives for the adaptation of spaces for PTWs have so far mostly been the initiative of private land or property managers, often in large shopping centres. However, the idea of multimodality is gaining more and more interest, gradually also from municipal authorities. Special parking zones for motorbikes and scooters have appeared in recent years in Warsaw, Płock, Łódź and Wrocław. These are, however, single locations with a small number of parking spaces in total and can only be described as the embryo of a wider system. In one of Warsaw's shopping centres, designated parking spaces for motorbikes were equipped with storage lockers of the Italian MotoParking ${ }^{\circledR}$ system—designed specifically for use in shopping centres and used in many of them in many European countries. Although parking facilities for motorbikes are still rare in the public space of Polish cities, a certain convenience and encouragement for local authorities to use them is certainly the fact that in most cities, 
motorcyclists in the areas of paid parking zones can park for free but only within the existing parking spaces. After research and tests conducted since 2014, Krakow was the first city in Poland to allow motorbike traffic on designated bus lanes on a stretch of several streets (Figure 8). Similar measures were then taken in other cities, such as Bydgoszcz, Łódź, Gdańsk, Szczecin, Rzeszów, Warsaw, Wrocław (only classic bus lanes, without tracks), Poznań and Kielce. Work on extending this possibility to other selected sections is in progress.
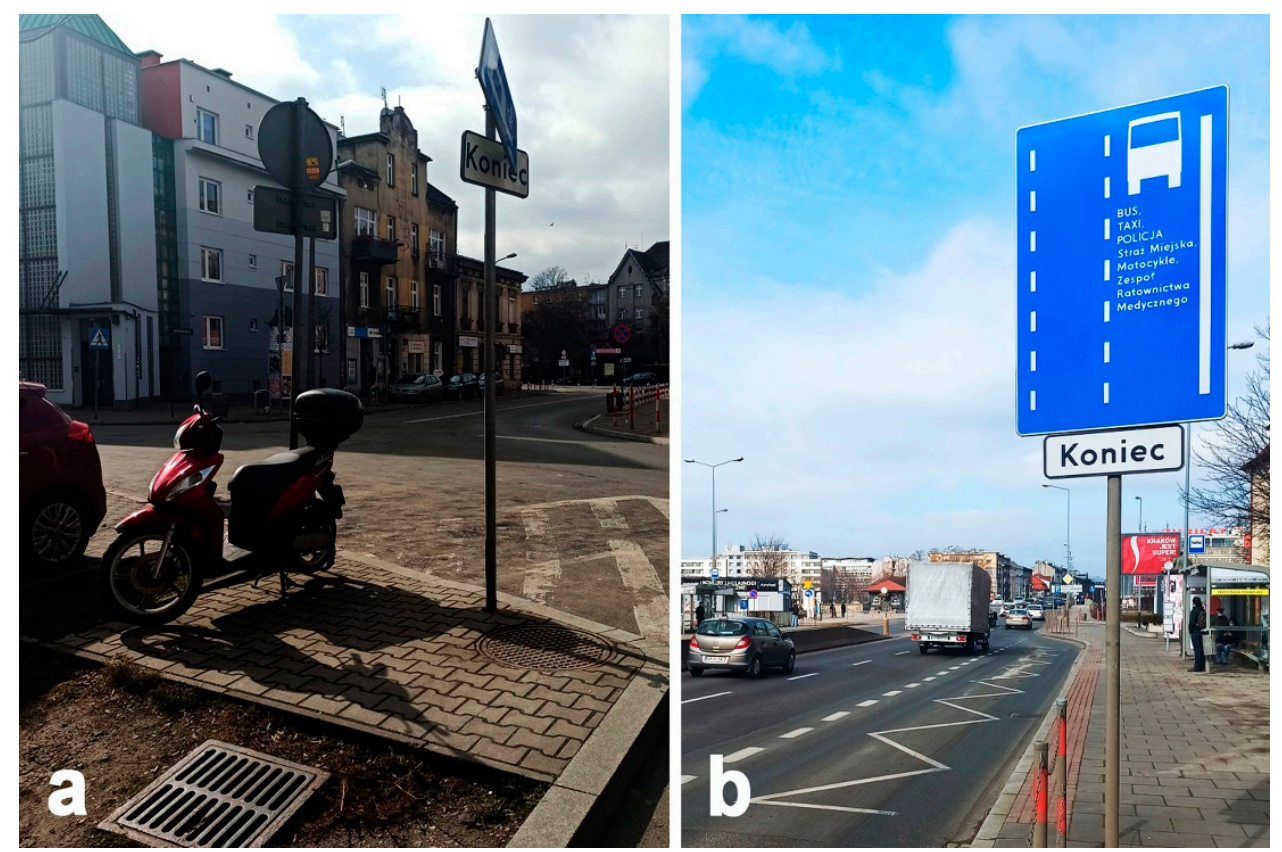

Figure 8. Kraków, Poland: (a) Scooter parked on a free fragment of the pavement, (b) end of the bus lane with motorbike traffic allowed. Source: Authors' archives (photo D. Wantuch-Matla).

\section{Results of the Research}

The described examples of developments for PTW users and problems related to the use of these vehicles can be found in all European cities (Figure 9). By analysing the examples of the transformation of public spaces in selected cities as well as their planning records, it is possible to illuminate the effects of translating statistics into real action in order to incorporate the potential of PTWs into inclusive and sustainable mobility policies (Table 1). The particularly interesting example of Barcelona, which is a kind of urban laboratory, shows that the inclusion of infrastructure elements for PTWs can turn the phenomenon of PTWs' extreme popularity into actions to increase the quality, attractiveness, accessibility and safety of urban spaces. At the same time, the developed infrastructure of PTW solutions may serve the constantly growing traffic of electric scooters and motorbikes. Thus, the research carried out allows us to confirm that PTW communication (including electric vehicles), next to the development of public transport, is one of the most effective methods of solving communication problems in cities $[69,115]$. Mopeds and motorcycles constitute a flexible and economic alternative for commuters and are widely used in urban areas where traffic density is high [116] This also applies to the centres located in the climate sphere with cold and snowy winters. Unlike rural areas, cities maintain the road passability to a greater extent, even during snowfall, which significantly impedes movement by two-wheelers. According to the research carried out by the authors in Poland, where both temperatures below zero degrees Celsius and snowfall occur, about 5\% of daily mobility during winter in cities is carried out mainly by mopeds [117]. This result is comparable with the share of bicycle transport during winter in cities, while in rural areas, it falls below 2\%. Technological developments and the observed climate warming [118] 
may influence the further popularisation of two-wheeler motorcycles in the temperate, cool climate sphere.
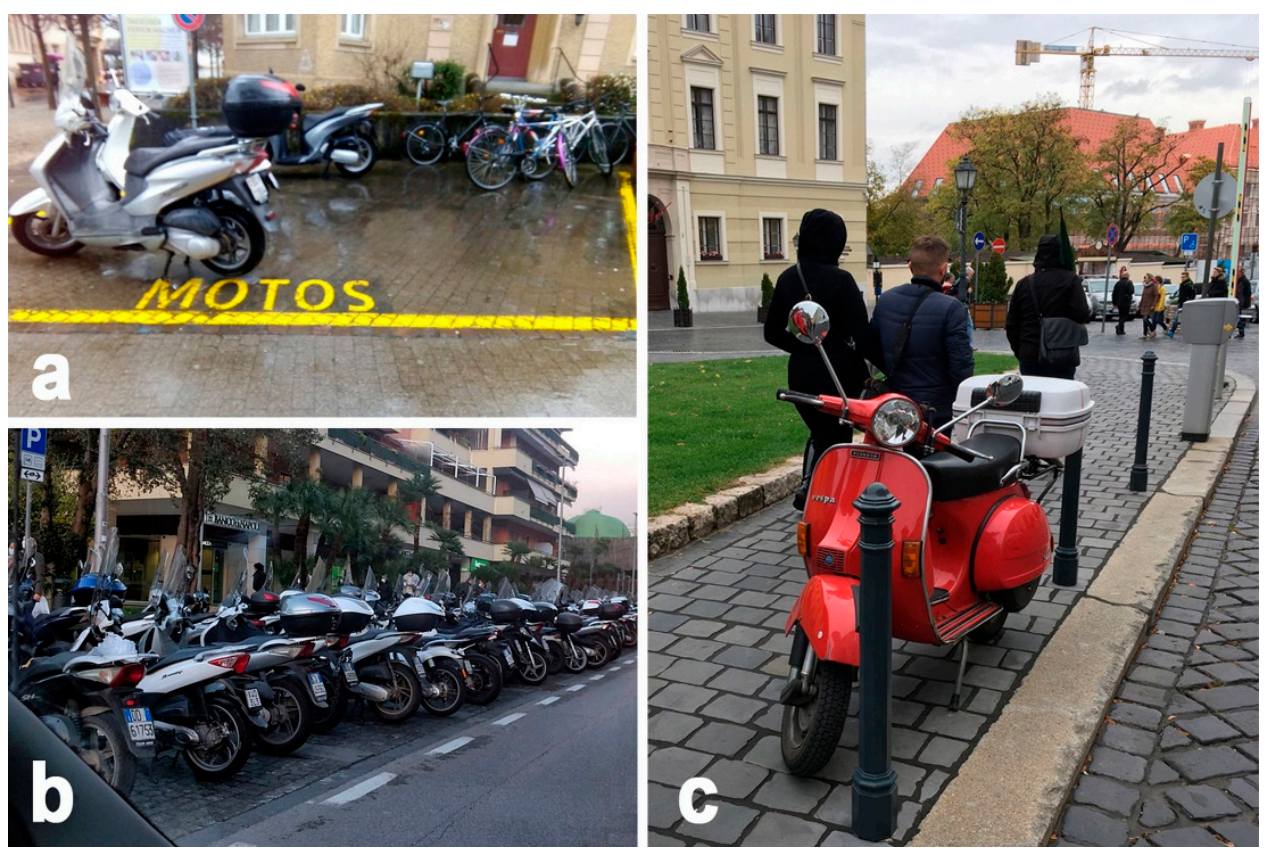

Figure 9. PTWs in use: (a) Basel, Switzerland-scooters parked in the special zone, (b) motorcycles squeezed in the popular area of Sorrento, Italy, (c) Budapest, Hungary-scooter parked freely on the side of the pavement. Source: Authors' archives (photos: A. Jenner (a); V. Somma (b); I. JastrzebskaDorocka (c)).

Considering the positive impact of PTW development in cities, two main factors should be noted. The first of these is travel time. Surveys carried out in Poland show that travel time by PTW in large cities is half that of cars (results from an online survey conducted by the authors). This applies mainly to city centres and peak traffic hours. This is supported by a study conducted in Belgium by Transport \& Mobility Leuven, which showed that if 10 per cent of all private cars are replaced by motorbikes, the total time loss for all vehicles would decrease by 40 per cent and total emissions would drop by 6 per cent. Based on these studies, a 25 per cent shift from cars to motorbikes was considered to completely eliminate traffic congestion [119].

The following factors influence the fact that it is faster to travel by motorcycle or moped than by car. First of all, users of two-wheelers in many countries can use so-called lane splitting with other vehicles [120]. Lane splitting is legal in most European countries. In some countries, such as France, the Netherlands, Spain and Italy, motorcyclists are expected to split lanes both in urban traffic and on roads outside the city, while in Germany, lane splitting is only expected when traffic is stopped or moving very, very slowly. According to surveyed single-track users in Poland, PTWs do not stand in traffic jams. An additional factor is the possibility for PTW users to use dedicated roadway zones for public transport. Such a solution is used in ten of the largest Polish cities (e.g., Kraków, Warsaw, Poznan, and Gdańsk). The possibility of driving a light vehicle through pedestrian crossings or traffic routes for pedestrians, in many cases, shortens the travel time. 
Table 1. Matrix presenting a comparative summary of the main elements of the analysis of the PTW situation in selected European cities. Author: D. Wantuch-Matla.

\begin{tabular}{|c|c|c|c|c|c|}
\hline & $\begin{array}{l}\text { Barcelona } \\
\text { (Spain) }\end{array}$ & $\begin{array}{l}\text { London (United } \\
\text { Kingdom) }\end{array}$ & Vienna (Austria) & $\begin{array}{l}\text { Stockholm } \\
\text { (Sweden) }\end{array}$ & Kraków(Poland) \\
\hline $\begin{array}{l}\text { Popularity of PTWs } \\
\text { (quantitative data) }\end{array}$ & $\begin{array}{c}484,300 \\
(2019) /(183 \text { per } \\
1000 \text { pop. })\end{array}$ & $\begin{array}{c}1,168,500 \\
(2019) /(130 \text { per } \\
1000 \text { pop. })\end{array}$ & $\begin{array}{c}91,400(2020) /(49 \\
\text { per } 1000 \text { pop. })\end{array}$ & $\begin{array}{c}65,400(2020) /(67 \\
\text { per } 1000 \text { pop. })\end{array}$ & $\begin{array}{l}\text { 32,300 (2019) } \\
\text { /(49 per } 1000 \\
\text { pop. })\end{array}$ \\
\hline $\begin{array}{l}\text { Visibility of spatial } \\
\text { solutions for PTWs in the } \\
\text { public space } \bullet \bullet \bullet \text { high } / \bullet \bullet \\
\text { moderate/• low }\end{array}$ & $\bullet \bullet \bullet$ & $\bullet \bullet$ & $\bullet \bullet$ & $\bullet \bullet$ & • \\
\hline $\begin{array}{l}\text { PTW theme in the local } \\
\text { planning and/or strategic } \\
\text { documents }\end{array}$ & $\begin{array}{l}\checkmark \\
\text { (extensive } \\
\text { strategy } \\
\text { dedicated to } \\
\text { policy on PTW } \\
\text { mobility in } \\
\text { the city) }\end{array}$ & $V$ & $\checkmark$ & $\checkmark$ & $x$ \\
\hline $\begin{array}{l}\text { Basic design standards for } \\
\text { motorcycle parking spaces, } \\
\text { bays, etc., in the national } \\
\text { planning documents }\end{array}$ & $\begin{array}{c}\checkmark \\
\text { (at the autonomy } \\
\text { and also } \\
\text { national level) }\end{array}$ & $\checkmark$ & $\checkmark$ & $\checkmark$ & $\checkmark$ \\
\hline $\begin{array}{l}\text { Non-governmental } \\
\text { associations/organisations } \\
\text { for motorcyclists, } \\
\text { publishing reports, } \\
\text { guidelines, etc., relevant at } \\
\text { the national level }\end{array}$ & not identified & $\checkmark$ & not identified & $\checkmark$ & $x$ \\
\hline $\begin{array}{l}\text { Separate city publications, } \\
\text { e.g., guidelines on the } \\
\text { provision of parking } \\
\text { spaces/parking facilities } \\
\text { for motorcycles in public } \\
\text { space }\end{array}$ & $\checkmark$ & $x$ & not identified & not identified & $x$ \\
\hline 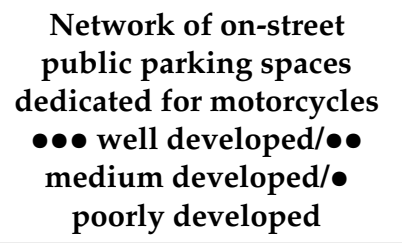 & $\bullet \bullet \bullet$ & $\bullet \bullet$ & $\bullet \bullet$ & $\bullet \bullet$ & $x$ \\
\hline $\begin{array}{l}\text { City apps with motorcycle } \\
\text { parking location map } \\
\text { (A)/City website with with } \\
\text { motorcycle parking } \\
\text { location map (W) }\end{array}$ & W & A & W & W & $x$ \\
\hline PTW allowed on bus lanes & $x$ & $\begin{array}{l}\text { partly, on } \\
\text { selected sections } \\
\text { of bus lanes }\end{array}$ & $\begin{array}{l}\text { partly, on } \\
\text { selected sections } \\
\text { of bus lanes }\end{array}$ & $\begin{array}{l}\text { partly, on } \\
\text { selected sections } \\
\text { of bus lanes }\end{array}$ & $\begin{array}{l}\text { partly, on } \\
\text { selected sections } \\
\text { of bus lanes }\end{array}$ \\
\hline
\end{tabular}

Another factor is the possibility of using partially closed traffic zones. Low emission zones produced throughout Europe limit road traffic. In most cases, the restrictions do not apply to electric vehicles, mainly two-wheelers. At the same time, fees related to the use of PTW vehicles in these zones are usually lower or zero. This is related to the space taken up by mopeds and light motorbikes, which occupy on average $1 / 4$ of the space needed for car parking. Related to this is another factor influencing the greater mobility of PTWs. This is the ease of parking. In Krakow (Poland), car drivers during rush hours spend about 
30 minutes parking their car, while in the case of two-wheelers, this problem is negligible. The problem of parking spaces is also visible in the case of a place of residence. The maladjustment of the spatial layout of residential estates built in the mid-20th century and modern guidelines for developers, who usually provide 1.5 parking spaces per apartment in Poland, has resulted in the residents seeking alternative solutions.

The advantage of PTWs over cars can also be seen in the speed of joining traffic. This can be seen when starting from traffic lights, especially in the case of scooters equipped with an automatic transmission. Due to their lower weight than cars and their small size, lightweight mopeds and scooters are characterised by high driving dynamics, which affect their speed and traffic flow in cities.

It can, therefore, be concluded that PTW vehicles in mixed traffic follow the "fugue" model. In road traffic, these vehicles fill free spaces, which are unsuitable for cars due to their size [121]. In Asian cities, two-lane, one-way traffic is carried out thanks to two-lane two-wheelers, with three somewhat informal two-lane lanes. Additionally, the ability to maneuver two-wheelers between vehicles ensures smooth traffic flow.

Along with high fluidity and no stoppages in traffic jams, PTW vehicles reduce exhaust emissions. An Italian comparison of the exhaust gas emissions of the Euro 4 gasoline passenger car and the Euro 3 scooter across Europe showed an advantage of the twowheeler in terms of both fuel consumption and emissions [122]. However, these values are different when there are more than two people traveling by car, which, however, is not common. Regardless of the results, mixed transport improves transport and reduces exhaust gas [123].

Nowadays, a lot of emphasis is placed on the popularisation of electric vehicles. However, in addition to the lack of emissions from the exhaust pipe, battery-powered cars emit PM25 from tire and brake wear and contribute to slowing down road traffic. We also have to remember that the carbon footprint associated with the production of a motorcycle is a fraction of that of any car. In addition, an important element is the source of obtaining electricity. In the case of Poland, where energy obtained from solid fuel combustion is dominant, the introduction of electric vehicles will not contribute to the overall reduction of exhaust emissions [124]. For these reasons, local authorities should take measures to promote mixed transport in order to improve the quality of life of city dwellers.

Confirmation of the effectiveness of the authorities' efforts to promote two-wheelers was verified by a survey. Differences in the use of PTWs by place of residence and type of vehicle are evident in the assessment of measures taken by local authorities to develop two-wheelers movement. When asked what national and local authorities consider to be the most appropriate measures to promote PTW, respondents gave the highest rating (on a scale of 1 to 5) to the provision of bus lanes for two-wheelers (4.1) (Figure 10). Bus lanes as an important amenity were rated higher by city dwellers facing traffic problems. However, the highest rating was given to this preference by motorbike owners living in the countryside. This may be related to the issue of commuting to work in the city and the morning and afternoon traffic jams formed on access and exit roads from the city. The second place, with a score of 3.8, was the exemption from fees, e.g., for parking or entering urban toll zones. In this case, also motorcyclists from rural areas rated this initiative of local authorities highest. Motorcyclists rated this measure much lower. This solution received much lower marks among moped users. A score of 3.3 was given to the proposal to allow the seasonal registration of vehicles, which, in the case of climatic conditions prevailing in Poland, may be very important (this involves a reduction in third party liability premium charges to $\frac{1}{2}$ of the amount). This proposal received more interest from moped owners, who are usually young people with limited financial means. A similar rating of about 3.2 was given to the proposal to create locks through traffic lights, which allows for more efficient traffic flow in cities (PTWs usually have a faster start than cars, especially small vehicles with automatic transmissions). This solution appealed most to motorbike drivers in the city. Car parks and a dedicated parking space for PTWs were the least popular. The 
lowest rating this idea had was with moped riders in rural areas where the problem of free parking spaces may be unknown to them.

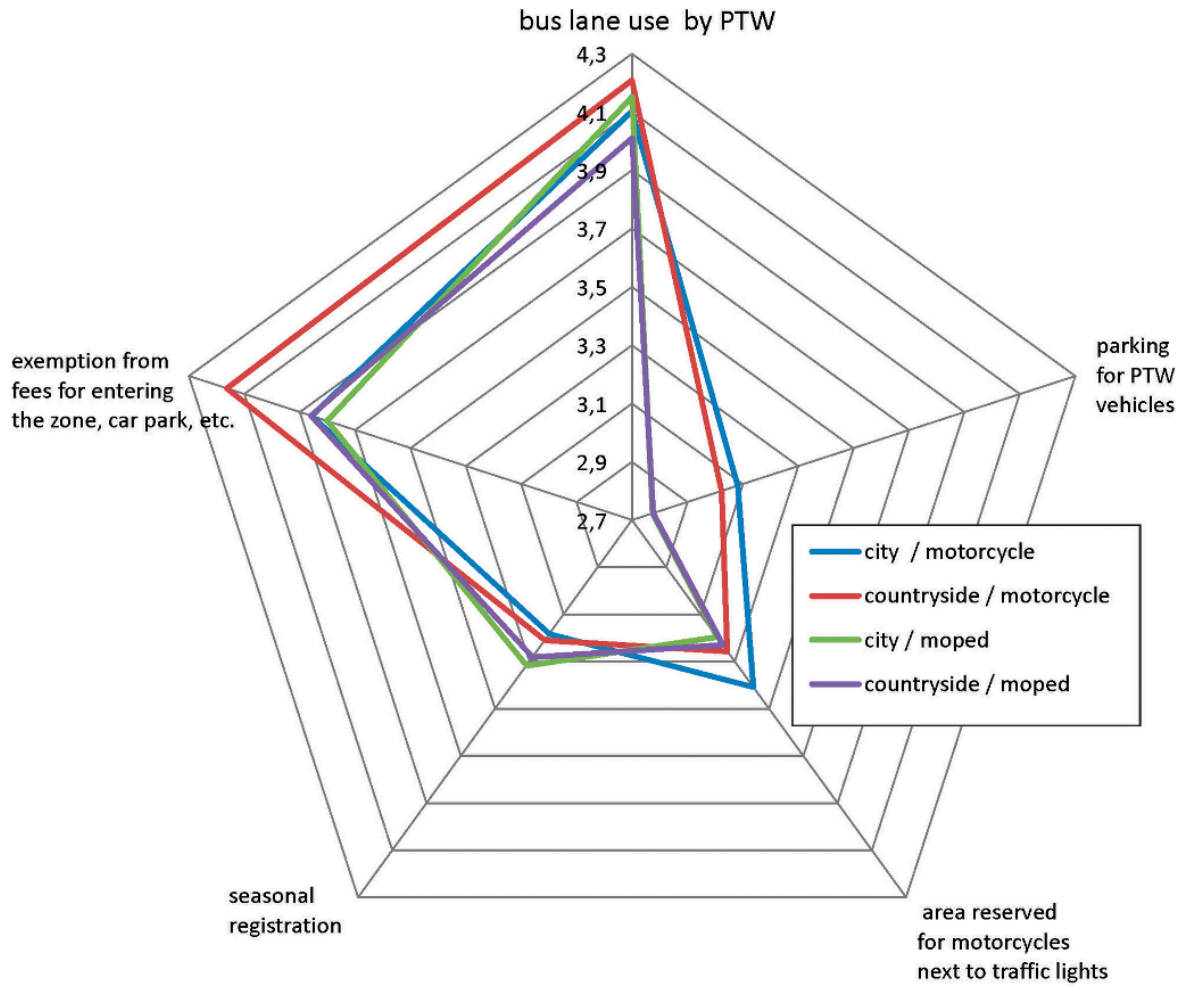

Figure 10. Respondents' evaluation of possible PTW promotion activities.

Other demands for action by local or national authorities included mainly the suggestion to differentiate or exempt toll motorways (as is the case in some European countries). Another demand was for a safe road infrastructure, examples being the use of motorcyclistfriendly energy barriers (many countries in Europe replace the old dangerous barriers) and non-slip horizontal markings on the road. Another important element was the proposal to organise free but compulsory courses and training not only for motorcyclists (to improve technical driving skills), but also for car drivers (there is still a belief in Poland that roads are only for cars). Among the postulates was the introduction of real road traffic education in primary and secondary schools (possibility to pass driving exams of different categories depending on the ages of students), subsidising sports facilities for motorbike sports and driving training.

It should be noted that the study referred to the conditions in Poland, where, despite the large increase in the popularity of two-wheelers, still only about $20 \%$ of users use these vehicles mainly for everyday transport.

In a survey carried out by PTW users, the best way to promote PTW use was to make lanes dedicated to public transport available for single wheelers. Exemption from fees for parking or entering restricted zones was ranked second. Then, there were locks for two-wheelers at intersections with traffic lights. Separate parking lots for two-wheelers were the least popular. In the context of top-down actions, the possibility of seasonal vehicle registration was indicated.

As regards the main problems reported by motorcyclists, the attitude of car drivers to two-wheelers (driving culture) was indicated. Other problems included the road infrastructure, mainly the condition of the road surface and the lack of anti-slip materials for horizontal signs placed on the road. 


\section{Discussion}

The subject of the conditions for the development of PTW in cities is highly controversial. First of all, attention should be drawn to the measures taken in many European cities to limit all traffic by combustion vehicles. However, also in this case, electric two-wheelers have an influence on the emission of environmental pollutants, even more so than cars. It should be emphasised that the complete exclusion of individual transport from cities in the experience of the COVID-19 pandemic seems very difficult; however, it requires further research. In addition, solutions dedicated to PTW vehicles can also affect the development of bicycle communication, including the increasingly popular electric bikes. Infrastructure network elements for PTW could be shared by users of other types of two-wheelers. This applies to both design solutions (e.g., parking lots for two-wheelers, shaping public spaces of streets and squares) and legal solutions (e.g., traffic filtering), or those related to road traffic organisation. In this context, Barcelona's approach is particularly noteworthy, as it proposes an inclusive mobility model that recognises different user groups in the pursuit of sustainable mobility. The design and legal regulation of PTWs (and not only PTWs) in the street space also help to clear up the chaos in the public space, while reinforcing the priority of pedestrians (pavements free from randomly parked vehicles and comfort and safety for pedestrians using the public space). Barcelona's concept of locating parking facilities for motorbikes, scooters and bicycles in the vicinity of intersections can increase the visibility and driving safety of all other road users.

A separate issue, however, is that PTWs (and also, electric two-wheelers), unlike bicycles, are not the most inclusive form of personal transport. They are not suitable as vehicles for children or a parent with more than one child, but on the other hand, they can support the mobility of people (including seniors) who cannot afford to cycle due to certain physical limitations.

Another issue not covered in this study is the safety of two-wheeled drivers. As shown by the latest research results in France, lane filtering poses a significant threat to two-wheeled drivers (Expérimentation de la circulation), which resulted in the ban on these practices from 1 February 2021. At the same time, their safety depends largely on other road users, which also requires separate studies.

\section{Conclusions}

The increase in the popularity of motorcycles and mopeds in Europe in the 21st century has its source both in the growing wealth of the society, mainly in Central and Eastern Europe, and in the development of urbanisation processes. The development of European cities causes increasing communication problems. In addition, attempts to reduce emissions in Europe are increasingly leading to measures to reduce the number of cars. The development of public transport, despite being the most optimal solution, entails high investment costs and often requires subsidies from public budgets. In addition, the experience of the COVID-19 pandemic points to major problems for many public transport operators. This has been influenced both by the lockdown introduced in many countries and by passengers' fear of using public transport. It therefore seems reasonable to stimulate various alternative means of transport in cities. PTW vehicles are one of them. Regardless of whether the vehicle is powered by an internal combustion engine or an electric engine, its advantage is determined by its greater mobility than in the case of cars or public transport. The lack of a sufficiently developed charging infrastructure for electric vehicles in many countries will continue to affect the advantage of motorised two-wheelers for a long time to come. An additional advantage of using two-wheelers is usually lower costs than in the case of a car. However, in order to popularise PTW vehicles in cities, actions by local authorities are necessary. These activities are both legislative, e.g., exemptions from parking fees, providing lanes for public transport, permit for lane filtering, as well as investment measures, e.g., the construction of roofed car parks for two-wheelers, the implementation of a network of parking zones, guidelines for areas reserved for two-wheelers by setting barriers for cars, guidelines for locks for two-wheelers at intersections, adaptation of road 
marking. The survey shows that the users of PTW vehicles in cities are most expected to provide dedicated lanes for public transport and financial concessions. The problem of parking lots for two-wheelers becomes important when parking restrictions are introduced, which is usually associated with the increase in their number. It seems that the expected solutions are the most optimal and do not affect the safety of motorcycle and moped users. On the other hand, the introduction of measures for equal rights for all road users is very important. This problem is particularly evident in Eastern and Central Europe, where until now, motorised traffic has been predominant, with motorcycles in urban traffic being the exception. The experience of introduced PTW solutions from European cities should form the basis for universal solutions. This is particularly important in the process of increasing the need for mobility in society.

Author Contributions: Conceptualization, S.D.; methodology, S.D. and D.W.-M.; software, S.D. and D.W.-M.; validation, S.D. and D.W.-M.; formal analysis, S.D.; investigation, S.D. and D.W.-M.; resources, S.D. and D.W.-M.; data curation, S.D. and D.W.-M.; writing-original draft preparation, S.D. and D.W.-M.; writing-review and editing, S.D. and D.W.-M.; visualization, S.D. and D.W.-M.; supervision, S.D. and D.W.-M.; project administration, S.D. and D.W.-M.; funding acquisition, S.D. and D.W.-M. All authors have read and agreed to the published version of the manuscript.

Funding: This research received no external funding.

Conflicts of Interest: The authors declare no conflict of interest.

\section{References}

1. Schafer, A.; Victor, D.G. The future mobility of the world population. Transp. Res. Part A Policy Pract. 2000, 34, 171-205. [CrossRef]

2. Banister, D. Cities, mobility and climate change. J. Transp. Geogr. 2011, 19, 1538-1546. [CrossRef]

3. Wolkinger, B.; Haas, W.; Bachner, G.; Weisz, U.; Steininger Karl, W.; Htter, H.-P.; Delcour, J.; Griebler, R.; Mittelbach, B.; Maier, P.; et al. Evaluationg Health Co-Benefits of Climate Change Mitigation in Urban Mobility. Int. J. Environ. Res. Public Health 2018, 15, 880. [CrossRef] [PubMed]

4. Cepeliauskaite, G.; Keppner, B.; Simkute, Z.; Leuser, L.; Kalnina, I.; Kotovica, N.; Andinš, J.; Muiste, M. Smart-Mobility Services for Climate Mitigation in Urban Areas: Case Studies of Baltic Countries and Germany. Sustainability 2021, 13, 4127. [CrossRef]

5. Arsenio, E.; Martens, K.; Di Ciommo, F. Sustainable urban mobility plans: Bridging climate change and equity targets? Res. Transp. Econ. 2016, 55, 30-39. [CrossRef]

6. European Commission. Annex. A Concept for Sustainable Urban Mobility Plans to the Communication from the Commission to the European Parliament, the Council, the European Economic and Social Committee and the Committee of the Regions. Together towards Competitive and Resource-Efficient Urban Mobility. Available online: https:/ / eur-lex.europa.eu/resource. html?uri=cellar\%3A82155e82-67ca-11e3-a7e4-01aa75ed71a1.0011.02/DOC_4\&format=PDF (accessed on 19 May 2021).

7. Rupprecht Consult. Guidelines for Developing and Implementing a Sustainable Urban Mobility Plan, Second Edition. 2019. Available online: https:/ / www.eltis.org/mobility-plans/sump-guidelines (accessed on 19 May 2021).

8. Smith, G.; Sochor, J.; Karlsson, I.M. Mobility as a Service: Development scenarios and implications for public transport. Res. Transp. Econ. 2018, 69, 592-599. [CrossRef]

9. Płaziak, M.; Szymańska, A.I. Preferencje młodych użytkowników przestrzeni miejskiej Krakowa w zakresie wyboru alternatywnych form transportu. Prace Komisji Geografii Przemystu Polskiego Towarzystwa Geograficznego 2019, 33, 36-57. [CrossRef]

10. Li, Y.; Voege, T. Mobility as a service (MaaS): Challenges of implementation and policy required. J. Transp. Technol. 2017, 7, 95-106. [CrossRef]

11. Połom, M. Międzynarodowe powiązania na rynku producentów trolejbusów w Europie w latach 2000-2014. Stud. Ind. Geogr. Comm. Pol. Geogr. Soc. 2017, 30, 75-90. [CrossRef]

12. Ellaway, A.; Macintyre, S.; Hiscock, R.; Kearns, A. In the driving seat: Psychosocial benefits from private motor vehicle transport compared to public transport. Transp. Res. Part F Traffic Psychol. Behav. 2003, 6, 217-231. [CrossRef]

13. Sharifi, A.; Khavarian-Garmsir, A.R. The COVID-19 pandemic: Impacts on cities and major lessons for urban planning, design, and management. Sci. Total Environ. 2020, 749, 142391. [CrossRef] [PubMed]

14. Politis, I.; Georgiadis, G.; Papadopoulos, E.; Fyrogenis, I.; Nikolaidou, A.; Kopsacheilis, A.; Sdoukopoulos, A.; Verani, E. COVID19 Lockdown Measures And Travel Behavior: The Case Of Thessaloniki, Greece. Transp. Res. Interdiscip. Perspect. 2021, 10, 100345. [CrossRef]

15. Campisi, T.; Basbas, S.; Skoufas, A.; Akgün, N.; Ticali, D.; Tesoriere, G. The Impact of COVID-19 Pandemic on the Resilience of Sustainable Mobility in Sicily. Sustainability 2020, 12, 8829. [CrossRef]

16. Torre-Bastida, A.I.; Del Ser, J.; Laña, I.; Ilardia, M.; Bilbao, M.N.; Campos-Cordobés, S. Big Data for transportation and mobility: Recent advances, trends and challenges. IET Intell. Transp. Syst. 2018, 12, 742-755. [CrossRef] 
17. Przybylowski, A.; Stelmak, S.; Suchanek, M. Mobility Behaviour in View of the Impact of the COVID-19 Pandemic-Public Transport Users in Gdansk Case Study. Sustainability 2021, 13, 364. [CrossRef]

18. Meena, S. Impactof novel Coronavirus (COVID-19) pandemic on travel pattern: A case study of India. Indian J. Sci. Technol. 2020, 13, 2491-2501. [CrossRef]

19. Fishman, E.; Cherry, C. E-bikes in the mainstream: Reviewing a decade of research. Transp. Rev. 2016, 36, 72-91. [CrossRef]

20. Raźniak, P.; Winiarczyk-Raźniak, A. Influence of the societal security level on population migrations in Poland. Procedia Soc. Behav. Sci. 2014, 120, 2-12. [CrossRef]

21. Fyhri, A.; Fearnley, N. Effects of e-bikes on bicycle use and mode share. Transp. Res. Part D Transp. Environ. 2015, 36, 45-52. [CrossRef]

22. Pucher, J.; Korattyswaropam, N.; Mittal, N.; Ittyerah, N. Urban transport crisis in India. Transp. Policy 2005, 12, 185-198. [CrossRef]

23. Sanko, N.; Maesoba, H.; Dissanayake, D.; Yamamoto, T.; Kurauchi, S.; Morikawa, T. Inter-temporal analysis of household car and motorcycle ownership behaviors: The Case in the Nagoya Metropolitan Area of Japan, 1981-2001. IATSS Res. 2009, $33,39-53$. [CrossRef]

24. Muzira, S.; Chesheva, E.; Banjo, G.; Marquez, P. Confronting "Death on Wheels" Making Roads Safe in Europe and Central Asia. Establishing Multisectoral Partnerships to Address a Silent Epidemic; Europe and Central Asia Human Development Department/The World Bank: Washington, DC, USA, 2009. [CrossRef]

25. Albalate, D.; Fernández-Villadangos, L. Motorcycle injury severity in Barcelona: The role of vehicle type and congestion. Traffic Inj. Prev. 2010, 1, 623-631. [CrossRef] [PubMed]

26. Pinch, P.; Reimer, S. Moto-mobilities: Geographies of the Motorcycle and Motorcyclists. Mobilities 2012, 7, 439-457. [CrossRef]

27. Uherek, E.; Halenka, T.; Borken-Kleefeld, J.; Balkanski, Y.; Berntsen, T.; Borrego, C.; Gauss, M.; Hoor, P.; Juda-Rezler, K.; Lelieveld, J.; et al. Transport impacts on atmosphere and climate: Land transport. Atmos. Environ. 2010, 44, 4772-4816. [CrossRef]

28. Mashayekh, Y.; Jaramillo, P.; Samaras, C.; Hendrickson, C.T.; Blackhurst, M.; MacLean, H.L.; Matthews, H.S. Potentials for sustainable transportation in cities to alleviate climate change impacts. Environ. Sci. Technol. 2012, 46, 2529-2537. [CrossRef] [PubMed]

29. Ballart, X.; Riba, C. Impact of legislation requiring moped and motorbike riders to wear helmets. Eval. Program Plan. 1995, 18, 311-320. [CrossRef]

30. Broughton, P.S.; Fuller, R.; Stradling, S.; Gormley, M.; Kinnear, N.; O'dolan, C.; Hannigan, B. Conditions for speeding behaviour: A comparison of car drivers and powered two wheeled riders. Transp. Res. Part F Traffic Psychol. Behav. 2009, 12, 417-427. [CrossRef]

31. Kopp, P. The unpredicted rise of motorcycles: A cost benefit analysis. Transp. Policy 2011, 18, 613-622. [CrossRef]

32. Karathodorou, N.; Graham, D.J.; Noland, R.B. Estimating the effect of Urban density on fuel demand. Energy Econ. 2010, 32, 86-92. [CrossRef]

33. Ng, W.S.; Schipper, L.; Chen, Y. China motorization trends: New directions for crowded cities. J. Transp. Land Use 2010, 3, 5-25. [CrossRef]

34. Yamamoto, T. Comparative analysis of household car, motorcycle and bicykle ownership between Osaka metropolitan area, Japan and Kuala Lumpur, Malaysia. Transportation 2009, 36, 351-366. [CrossRef]

35. Lam, W.; Tam, M. Reliability of territory-wide car ownership estimates in Hong Kong. J. Transp. Geogr. 2002, 10, 51-60. [CrossRef]

36. Clark, S.D. Estimating local car ownership models. J. Transp. Geogr. 2007, 15, 184-197. [CrossRef]

37. Clark, S.D. Charactering and predicting car ownership using rough sets. Transp. Res. Part C Emerg. Technol. 2009, 17, 381-393. [CrossRef]

38. Khan, A.; Willumsen, L. Modelling car ownership and use in developing countries. Traffic Eng. Control 1986, $27,554-560$.

39. Hess, B.D.; Ong, P. Traditional Neighborhoods and Automobile Ownership. Transp. Res. Rec. J. Transp. Res. Board 2002, 1805, 35-44. [CrossRef]

40. Riley, K. Motor vehicles in China: The impact of demographic and economic changes. Popul. Environ. 2002, 23, 479-494. [CrossRef]

41. Haworth, N. Powered two wheelers in a changing world: Challenges and opportunities. Accid. Anal. Prev. 2012, 44, 12-18. [CrossRef] [PubMed]

42. Dargay, J.; Gately, D. Income's effect on car and vehicle ownership, worldwide: 1960-2015. Transp. Res. Part A Policy Pract. 1999, 33, 101-138. [CrossRef]

43. De Jong, G.C.; Van de Riet, O. The driving factors of passenger transport. Eur. J. Transp. Infrastruct. Res. 2008, 8, 227-250. [CrossRef]

44. Schwanen, T.; Dijst, M.; Dieleman, F.M. Policies for urban form and their impact on travel: The Netherlands experience. Urban Stud. 2004, 41, 579-603. [CrossRef]

45. Nishitateno, S.; Burke, P.J. The motorcycle Kuznets curve. J. Transp. Geogr. 2014, 36, 116-123. [CrossRef]

46. Marquet, O.; Miralles-Guasch, C. City of Motorcycles. On how objective and subjective factors are behind the rise of two-wheeled mobility in Barcelona. Transp. Policy 2016, 52, 37-45. [CrossRef]

47. Paviotti, M.; Vogiatzis, K. On the outdoor annoyance from scooter and motorbike noise in the urban environment. Sci. Total Environ. 2012, 430, 223-230. [CrossRef]

48. Jong, G.D.; Fox, J.; Daly, A.; Pieters, M.; Smit, R. Comparison of car ownership models. Transp. Rev. 2004, 24, 379-408. [CrossRef] 
49. Lai, W.T.; Lu, J.L.; Chiang, Y.S. The study of multi-vehicle household mix demand model on auto-motorcycle ownership and use in Taiwan area. Transp. Plan. J. 2006, 35, 309-336.

50. Chiou, Y.C.; Wen, C.H.; Tsai, S.H.; Wang, W.Y. Integrated modelling of car/motorcycle ownership, type and usage for estimating energy consumption and emissions. Transp. Res. Part A Policy Pract. 2009, 43, 665-684. [CrossRef]

51. Pongthanaisawan, J.; Sorapipatana, C. Relationship between level of economic development and motorcycle and car ownerships and their impacts on fuel consumption and greenhouse gas emission in Thailand. Renew. Sustain. Energy Rev. 2010, 14, 2966-2975. [CrossRef]

52. Law, T.H.; Hamid, H.; Goh, C.N. The motorcycle to passenger car ownership ratio and economic growth: A cross-country analysis. J. Transp. Geogr. 2015, 46, 122-128. [CrossRef]

53. Perez, K.; Borrell, C.; Nebot, M. Road injuries and relaxed licensing requirements for driving light motorcycles in Spain: A time-series analysis. Bull. World Health Organ. 2009, 87, 497-504. [CrossRef]

54. Delhaye, A.; Marot, L. The Motorcycling Community in Europe; Deliverable 9 of the EC/MOVE/C4 project RIDERSCAN; Federation of European Motorcyclists' Associations (FEMA): Etterbeek, Belgium, 2015; Available online: https://ec.europa.eu/transport/ road_safety/sites/roadsafety/files/pdf/projects_sources/riderscan_d9.pdf (accessed on 8 January 2021).

55. Karthaus, M.; Falkenstein, M. Functional Changes and Driving Performance in Older Drivers: Assessment and Interventions. Geriatrics 2016, 1, 12. [CrossRef] [PubMed]

56. Bucchiarone, A.; Battisti, S.; Dias, T.G.; Feldman, P. Guest Editorial Diversification in Urban Transportation Systems and Beyond: Integrating People and Goods for the Future of Mobility. IEEE Trans. Intell. Transp. Syst. 2021, 22, 2008-2012. [CrossRef]

57. Banister, D. The sustainable mobility paradigm. Transp. Policy 2008, 15, 73-80. [CrossRef]

58. van Wee, B. Land use and transport: Research and policy challenges. J. Transp. Geogr. 2002, 10, 259-271. [CrossRef]

59. Miłaszewicz, D.; Ostapowicz, B. Warunki zrównoważonego rozwoju transportu w świetle dokumentów UE. Studia $i$ Prace Wydziału Nauk Ekonomicznych i Zarzadzania 2011, 24, 103-118.

60. Hebel, K. Nowa kultura mobilności w polskich miastach. Zeszyty Naukowe Uniwersytetu Gdańskiego. Ekonomika Transportu i Logistyka 2017, 62, 67-78.

61. Gil, A.; Calado, H.; Bentz, J. Public participation in municipal transport planning processes-the case of the sus-tainable mobility plan of Ponta Delgada, Azores, Portugal. J. Transp. Geogr. 2011, 19, 1309-1319. [CrossRef]

62. Wyszomirski, O. Zrównoważony rozwój transportu w miastach a jakość życia. Transp. Miej. I Reg. 2017, 12, 27-32.

63. Persia, L.; Cipriani, E.; Sgarra, V.; Meta, E. Strategies and Measures for Sustainable Urban Transport Systems. Transp. Res. Procedia 2016, 14, 955-964. [CrossRef]

64. Geoffrey, R.; Delbos, A. Understanding the Use of Powered Two-Wheelers for Commuting: Case Study of Melbourne. In TRB 93rd Annual Meeting Compendium of Papers; Skinner, R.E., Jr., Ed.; Transportation Research Board: Washington, DC, USA, 2014; pp. $1-10$.

65. Delbosc, A.; Rose, G. Powered-two-wheeler usage patterns on Melbourne tollways. In Transport and the New World City: 36th Australasian Transport Research Forum (ATRF); Oxlad, L., Ed.; Queensland University of Technology: Brisbane, Australia, 2013; Available online: https://www.australasiantransportresearchforum.org.au/sites/default/files/2013_delbosc_rose.pdf (accessed on 2 May 2021).

66. Basbas, S.; Oikonomou, A.; Politis, I. The role of on-street urban parking schemes for power two wheels in sustainable mobility. In Proceedings of the 5th International Conference: Urban Regeneration and Sustainability-The Sustainable City; Gospodini, A., Brebbia, C.A., Tiezzi, E., Eds.; Wit Press: Southampton, UK, 2008; pp. 435-444.

67. Jordehi, B.A.; Rose, G.; Thompson, R.G. Motorcycle and motor scooter use in Victoria, Australia. Transp. Res. Rec. 2013, 2388, 61-70. [CrossRef]

68. Jordehi, B.A.; Rose, G. Understanding the Ownership of Powered Two Wheel Vehicles in Victoria, Australia. Int. J. Sci. Technol. 2014, 2, 99-104.

69. Eccarius, T.; Chung-Cheng, L. Powered two-wheelers for sustainable mobility: A review of consumer adoption of electric motorcycles. Int. J. Sustain. Transp. 2020, 14, 215-231. [CrossRef]

70. Brunner, H.; Hirz, M.; Hirschberg, W.; Fallast, K. Evaluation of various means of transport for urban areas. Energy Sustain. Soc. 2018, 8. [CrossRef]

71. Barmpounakis, E.N.; Vlahogianni, E.I.; Golias, J.C. Intelligent Transportation Systems and Powered Two Wheelers Traffic. IEEE Trans. Intell. Transp. Syst. 2016, 17, 908-916. [CrossRef]

72. Livett, G. The Contribution Motorcycles Can Make to Sustainable Transport in London. Ph.D. Thesis, UCL (University College London), London, UK, 2007.

73. Dorocki, S. Changes in the Market of Two and Three-wheeled Motor Vehicles in Europe at the Beginning of the 21st Century. Entrep. Bus. Econ. Rev. 2018, 6, 175-193. [CrossRef]

74. Nagai, Y.; Fukuda, A.; Okada, Y.; Hashino, Y. Two-wheeled vehicle ownership trends and issues in the Asian region. J. East. Asia Soc. Transp. Stud. 2003, 5, 135-146.

75. Evans, J.R.; Mathur, A. The value of online surveys. Internet Res. 2005, 15, 195-219. [CrossRef]

76. Siva Durga Prasad Nayak, M.; Narayan, K.A. Strengths and weakness of online surveys. IOSR J. Humanit. Soc. Sci. 2019, 24, 31-38. [CrossRef] 
77. Barcelona No Tiene Espacio Para Aparcar Miles De Motocicletas, El Pais. Available online: https://elpais.com/ccaa/2019/03/30 / catalunya/1553968061_332678.html (accessed on 2 May 2021).

78. Klanjčić, B.; Gauvin, M.; Tizzoni, L.; Szell, M. Identifying Urban Features for Vulnerable Road User Safety in Europe. 2021. Available online: https:/ / osf.io/download/6076de84f6585f0637614b51/ (accessed on 2 May 2021).

79. The Mayor's Transport Strategy. Available online: https://tfl.gov.uk/corporate/about-tfl/the-mayors-transport-strategy (accessed on 2 May 2021).

80. Najbardziej Zakorkowane Miasta W Polsce. Dwa Z Nich Są W Pierwszej Dziesiątce Najbardziej Zatłoczonych W Europie Mo-to.pl. Available online: https: / / moto.pl/MotoPL/7,88389,25648861,najbardziej-zakorkowane-miasta-w-polsce-dwa-z-nich-sa-wpierwszej.html (accessed on 2 May 2021).

81. Dorocki, S. Przemysł dwu-i trzykołowych pojazdów silnikowych (PTW) w Europie. Przykład Piaggio Group. Prace Komisji Geografii Komunikacji PTG 2018, 21, 65-79. [CrossRef]

82. Van Elslande, P.; Feypell-de La Beaumelle, V.; Holgate, J.; Redant, K.; De Solere, H.; Margaritis, D.; Granström, P.O. Mobility and safety of powered two-wheelers in the OECD countries. In Traffic Safety; Yannis, G., Cohen, S., Eds.; Wiley: London, UK, 2016; Volume 4, pp. 101-117. [CrossRef]

83. Ragnoli, A.; Vittoria Corazza, M.; Di Mascio, P. Safety ranking definition for infrastructures with high PTW flow. J. Traffic Transp. Eng. 2018, 5, 406-416. [CrossRef]

84. International Transport Forum. Road Safety Annual Report 2020. OECD/IRTAD. Available online: https://www.itf-oecd.org/ road-safety-annual-report-2020 (accessed on 15 February 2021).

85. Dudzic-Gyurkovich, K. Pokonywanie Barier Urbanistycznych Zwiąanych Z Układami Transportu Na Obszarze Metropolii Barcelońskiej. Wybrane Problemy; Wydawnictwo Politechniki Krakowskiej: Kraków, Poland, 2019; pp. 92-116.

86. Monclús, F.J. The Barcelona model: And an original formula? From 'reconstruction' to strategic urban projects (1979-2004). Plan. Perspect. 2010, 18, 399-421. [CrossRef]

87. Marshall, T. Transforming Barcelona: The Renewal of a European Metropolis; Routledge: New York, NY, USA, 2004 ; p. 18.

88. Perez Diez, F.; Campos Cacheda, M.; Cabrerizo Sinca, J. Stage of historical evolution of private vehicle ownership in the city of Barcelona. Tansportation Res. Procedia 2016, 18, 140-147. [CrossRef]

89. Areaverda. Available online: https:/ / www.areaverda.cat/en/motorcycles (accessed on 18 December 2020).

90. PMU 2013-18. El Pla de Mobilitat Urbana 2012-2018. Available online: http://www.bcnecologia.es/sites/default/files/ proyectos/pmu-bcn-2013-2018_introduccio_i_diagnosi.pdf278-280 (accessed on 28 December 2020).

91. DGT Catálogo de Experiencias de Seguridad Vial Urbana en España. pp. 31-33. Available online: https:/ /issuu.com/ecourbano/ docs / catalogo-experiencias-seguridad-vial (accessed on 28 December 2020).

92. Pérez, K.; Santamariña-Rubio, E. 2068-Are Barcelona's Advanced Zones for Motorcycles Effective? J. Transp. Health 2017, 5, 47. [CrossRef]

93. B:SM. Motorbike Challenge. Parking Can Make It. 2019. Available online: https://www.europeanparking.eu/media/1543/4 _spain_barcelona_-bsm_motorbikechallenge_presentation.pdf (accessed on 15 November 2020).

94. Ayuntamiento de Madrid. Instrucción Vía Pública del Ayuntamiento de Madrid. Available online: https://www. madrid.es/portales/munimadrid/es/Inicio/Vivienda-y-urbanismo/Publicaciones/Instruccion-para-el-Diseno-de-la-ViaPublica?vgnextfmt=default\&vgnextoid=ebbdac0c317cf110VgnVCM2000000c205a0aRCRD\&vgnextchannel=cf6031d3b28fe410 VgnVCM1000000b205a0aRCRD (accessed on 8 January 2021).

95. Urbanismosevilla Definición de las Áreas de Estacionamiento para Movilidad Compartida (AEMC) de los Vehículos de Movilidad Personal (VMP) Proyecto, S.I.G. Sistema de Información Geográfica. Available online: https://www.urbanismosevilla.org/ areas/sostenibilidad-innovacion/sevilla-en-bici/proyecto-piloto-implantacion-servicio-explotacion-vehiculos-de-movilidadpersonal-1/proyecto-piloto-implantacion-servicio-explotacion-vehiculos-de-movilidad-personal (accessed on 6 January 2021).

96. Statista. Available online: https://www.statista.com/statistics/312594/motorcycle-and-car-registrations-in-the-unitedkingdom/ (accessed on 8 January 2021).

97. Government Office for Science. A Time of Unprecedented Change in the Transport System. The Future of Mobility. 2020. Available online: https://assets.publishing.service.gov.uk/government/uploads/system/uploads/attachment_data/file/78 0868/future_of_mobility_final.pdf (accessed on 8 January 2021).

98. Department for Transportation. Local Transport Note 1/07. Traffic Calming. Available online: https://www.gov.uk/government/ publications / traffic-calming-ltn-107 (accessed on 27 December 2020).

99. Department for Transportation. Transport Statistic Bulletin. Compendium of Motorcycling Statistics 2009. National Statistics. Available online: https:/ /www.motorcycleguidelines.org.uk/wp-content/uploads/2013/08/motorcyclingstats2009.pdf (accessed on 3 January 2021).

100. Department for Transportation. Manual for the Streets. Available online: https://issuu.com/ihiemcguidelines-ch1/docs/ completeguidelinesv1.1 (accessed on 3 January 2021).

101. Department for Transportation. Traffic Advisory Leaflet. The Use of Bus Lanes by Motorcycles. Available online: https: //www.motorcycleguidelines.org.uk/wp-content/uploads/2013/08/tal-2-07.pdf (accessed on 3 January 2021).

102. Insitute of Highway Engineers. Available online: http://www.motorcycleguidelines.org.uk/the-guidelines/6-0-motorcycleparking/6-1-summary/ (accessed on 7 January 2021). 
103. Insitute of Highway Engineers. Available online: http:/ /www.motorcycleguidelines.org.uk/the-guidelines/3-0-road-designtraffic-engineering/3-5-traffic-engineering/ (accessed on 7 January 2021).

104. British Motorcyclists Federation. Parking for Motorcycles and Scooters. A Resource Guide. Available online: http:// motorcycleguidelines.org.uk/wp-content/uploads/2013/08/BMFPARKI.pdf (accessed on 7 January 2021).

105. British Parking Association. Available online: https://www.britishparking.co.uk/write/Documents/Library\%202016/Bay_ Sizes_-_Jul_2016.pdf (accessed on 16 November 2020).

106. Sveriges MotorCyklister. The Motorcycle Vision 2.0; Sveriges MotorCyklister: Borlänge, Sweden, 2014; Available online: https: //www.svmc.se/smc/SMCs-arbete--fragor/MC-VISIONEN-20/ (accessed on 14 January 2021).

107. Swedish Transport Administration. Increased Safety on Motorcycles and Mopeds Combined Strategy Version 3.0 for the Years 2016-2020; Trafikverket: Borlänge, Sweden, 2016; Available online: https:/ / trafikverket.ineko.se/se/tv000475 (accessed on 12 January 2021).

108. Government Offices of Sweden. Strategy for Livable cities. Available online: https://www.government.se/information-material/ 2018/06/strategy-for-liveable-cities/ (accessed on 12 January 2021).

109. Road Safety Sweden. Available online: https://www.roadsafetysweden.com/contentassets/b37f0951c837443eb9661668d5be439 e/stockholm-declaration-english.pdf (accessed on 21 January 2021).

110. Motorcycleminds. Available online: https:/ / motorcycleminds.org/2018/04/12/high-parking-fees-sweden/ (accessed on 20 January 2020).

111. UMPV. Thematic Concept. Urban Mobility Plan Vienna Together on the Move. Available online: https://www.wien.gv.at/ stadtentwicklung/studien/pdf/b008443.pdf (accessed on 4 January 2021).

112. StadtWien 1. Available online: https:/ / www.wien.gv.at/verkehr/verkehrssicherheit/safebike/entwicklung.html (accessed on 6 January 2021).

113. StadtWien 2. Available online: https://www.wien.gv.at/verkehr/verkehrssicherheit/safebike/busspuren.html (accessed on 6 January 2021).

114. Brussels. Available online: https://www.brussels.be/sites/default/files/bxl/Urbanisme\%20et\%20logement/charte-mobolitemoto-fr.pdf (accessed on 8 January 2021).

115. Santucci, M.; Pieve, M.; Pierini, M. Electric L-category vehicles for smart urban mobility. Transp. Res. Procedia 2016 14, $3651-3660$. [CrossRef]

116. Theofilatos, A.; Yannis, G. Investigation of powered 2-wheeler accident involvement in urban arterials by considering real-time traffic and weather data. Traffic Inj. Prev. 2017, 18, 293-298. [CrossRef] [PubMed]

117. Dorocki, S. Użytkowanie motocykli i motorowerów w Polsce na początku XXI wieku. Prace Komisji Geografii Komunikacji PTG 2019, 22, 34-45. [CrossRef]

118. Twardosz, R.; Kossowska-Cezak, U. Large-area thermal anomalies in Europe (1951-2018). Temporal and spatial patterns. Atmos. Res. 2020, 251, 105434. [CrossRef]

119. Hanlon, M. New Research Indicates Motorcycle Commuting Reduces Traffic Congestion And Emissions, New Atlas, 13 February 2012. Available online: https:/ / newatlas.com/motorcycles-reduce-congestion/21420/ (accessed on 8 January 2021).

120. Clabaux, N.; Fournier, J.Y.; Michel, J.E. Powered two-wheeler riders' risk of crashes associated with filtering on urban roads. Traffic Inj. Prev. 2017, 18, 182-187. [CrossRef]

121. Lee, T.C.; Polak, J.W.; Bell, M.G. New approach to modeling mixed traffic containing motorcycles in urban areas. Transp. Res. Rec. 2009, 2140, 195-205. [CrossRef]

122. Murena, F.; Prati, M.V.; Costagliola, M.A. Real driving emissions of a scooter and a passenger car in Naples city. Transp. Res. Part D Transp. Environ. 2019, 73, 46-55. [CrossRef]

123. Monks, P. (Ed.) Non-Exhaust Emissions from Road Traffic. Available online: https:/ /uk-air.defra.gov.uk/assets/documents/ reports/cat09/1907101151_20190709_Non_Exhaust_Emissions_typeset_Final.pdf (accessed on 8 January 2021).

124. Knobloch, F.; Hanssen, S.V.; Lam, A.; Pollitt, H.; Salas, P.; Chewpreecha, U.; Huijbregts, M.A.J.; Mercure, J.-F. Net emission reductions from electric cars and heat pumps in 59 world regions over time. Nat. Sustain. 2020, 3, 437-4471. [CrossRef] [PubMed] 